HINTS AND HELPS Nov. HORSEMEN. 


\section{$8 \times 87 \frac{40}{5}$}

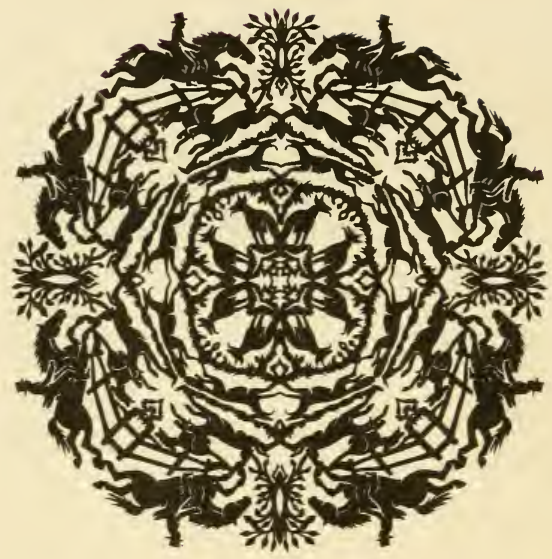

JOHN A.SEAVERNS 






\section{HINTS AND HELPS}

To

\section{HORSEMEN.}

$\triangle$ IIANDY MANUAL FOR

\section{HORSEKEEPERS;}

WITH THE RACING AND BETTING RULES OF THE AMERICAN JOCKEY CLUB.

13y "SPERRY." 
Entered according to act of Congress, in the year 1877 , by ALBERT COGSWELL,

in the omce of the Librarian of Congress, at Washington. 


\section{INTRODUCTION.}

A great many years have passed since a work on the horse has been published, and during those intervening years, a complete revolution has taken place in the training and treatment of the noble animal. It is the intention of the author to present, in as concise form as possible, and with words so plain, that everybody who speaks the English language can readily understand it, all the modern improvements in the breeding, training, and remedies for the different complaints that the horse is heir to, will be given under their proper heads, in such a way that there can be no mistake made.

In presenting this little volume to the public, we desire to state that, while it is not as comprehensive in space as some earlier books on the same subject, it will contain nothing but facts that can be relied on, and with this idea we launch it forth; hoping that every farmer and lover of horses in our broad country will become interested in and commend it. 


\section{CONTENTS.}

CHAPTER FIRST.

PAGE.

The Breeding of Horses and the Choice of Sire.............. 5

CHAPTER SECOND.

The Choice of Mares in Breeding.......................... 9

CHAPTER THIRD.

The Proper Age to Breed frox.......................... 14

CHAPTER FOURTH.

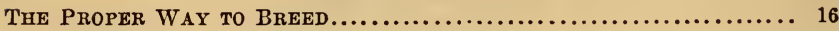

CHAPTER FIFTH.

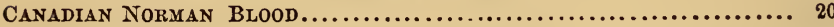

CHAPTER SIXTH.

ARABIAN BLOOD TOO MUCH PUfFEd UP.......................... 24

CHAPTER SEVENTH.

АвоUT PoniEs............................................ 25

CHAPTER EIGHTH.

CHAPTER NINTH.

PoINTS IN HoRse Buring.

CHAPTER TENTH.

HINTS IN REgaRd TO THE LEgS AND FEeT..................... 37

CHAPTER ELEVENTH.

The Proper Way to Feed a Horse

CHAPTER TWELFTH.

The Stable and its ATtendaNts

CHAPTER THIRTEENTH.

The Proper Way to Break a Horse

CHAPTER FOURTEENTH.

Simple Diseases Cuked By Simple Means................... 5

CHAPTER FIFTEENTH.

HOMGPATHY FOR THE HORSE............................ 61

CHAPTER SIXTEENTH.

What Veterinary SURgeons Do............................ 76

CHAPTER SEVENTEENTH.

THE PROPER way to ShOE a HoRse....................... 80

CHAPTER EIGHTEENTH.

CHAPTER NINETEENTH. 


\section{HINTS AND HELPS T0 HORSEMEN.}

\section{CHAPTER FIRST.}

THE BREEDING OF HORSES AND CHOICE OF SIRES.

There is no country in the world where the horse is more valuable than in the United States; and he adds to the national wealth in no small degree. Among farmers, the desire to raise good stock is increasing wonderfully; and among persons of leisure and wealth, the desire to own fast and valuable horses is indeed great. The profit to be derived from the raising of good horses is immense, and the number of people who have made fortunes in the business attest that fact ; but at the same time, there have been many who have become bankrupt, and all because their knowledge was limited. It is cheaper in the end to keep a good horse than it is to keep a bad one; and this fact is becoming perceptible to all lovers of the noble animal, for the feed costs the same; the stable room is no smaller, and the useful animal will last a great deal longer than the poor, broken-down jade.

In fact, a horse four years old, bought at three or four hundred dollars will, when he has attained his maturity, be worth twice the money, either for sale or work; while one bought for a third that price will be completely worn out and unfit for anything; and the better the horse is in the first instance, the more rapid will be the increase in his value. 
What is it that constitutes value in every horse? It is quickness of action, power to carry weight, and endurance: having bottom enough to travel a long distance at the same gait, and be able to work year in and year out, with the same strength and vigor. And it is unnecessary to say, that all this cannot be done, unless the animal has the highest breeding and higher degree of health. In former days, it was the fashion to underrate the value of speed, and to laugh at the advantage of blood; but all this has materially changed, and the owner of every horse in these days knows that "blood will tell."

The horse that can do twice as much work as another, and that can travel twice the distance in the same time, is certainly worth twice as much to his owner, as the other one.

The question now is : How is this result to be reached? By getting the greatest amount of pure blood into the animal bred, consistent with his size and power, and the purpose he is intended to be used for. Speed alone is not the only good thing to be derived from blood, for blooded horses possess double the endurance, and spirit of resistance, that the cart horse does in his coldness of blood. Beyond this, the internal construction of his respiratory organs and of his general constitution, is enough to give him greater physical power in proportion to his size, than any other animal ; adding to a greater courage, endurance, suffering, and fleetness of movement.

It is not to be said, however, that all blooded horses are alike in these qualities, for there is more judgment to be used in the choice of blooded horses, than in any other of the species. In the blood of the thoroughbred, all diseases, faults and vices come from their originators, and the same may be said of all his good qualities; but in selecting a thoroughbred, his record and that of his ancestors should be inquired into.

Those who breed from a short horse, in hopes of getting a large colt, will find out their mistake when it is too late; and so it will be 
with those who expect to get perfection out of a spavined, ringboned, or a dunghill of a horse. The blood should always be on the side of the sire, and for farmers' breeding purposes, the sire should be of medium height, short backed, well ribbed up, short in the saddle place, long below. He should have a broad chest, broad loins, straight rump, and high withers; a lean, bony, well-set head; a clear, bright and well placed eye ; small ears and broad nostrils. His fore legs should be as long as possible above the knee, and his hind legs above the hock, and as lean, short and bony as can be below those joints. The sinews should be clear, straight, firm and hard to the touch. From such a horse and a well-chosen roomy mare, he can be certain of owning a fine colt.

The point to be looked after is, combination of speed in conncction with strength, and, at the same time, to look out for disease or deformity in either of the parents. The first point will be reached by breeding to pure blood, and by breeding to what is called $u p$, not down; that is, by breeding the dam to a sire of superior blood; except when it is desired to breed in and in, for the purpose of getting a pure strain, which may be serviceable in the get of brood mares.

A half-bred mare should never be put to - a half-bred stallion, as in that case, the produce will degenerate below the dam. Whereas, the get of a thoroughbred will be superior, and will continue to improve, if the same process of breeding up is carried out.

All diseases of the lungs and windpipe, commonly called the heaves, such as broken wind, roaring, whistling, thick wind and such like, are transmitted from the parents. Blindness is more so, and when one eye is destroyed by accident, and the other through sympathy should follow it, then it is not safe to breed from a horse so injured. Lameness arising from accident, is not transmissible; but when a horse has broken down in running, it wilı be best to observe whether there is not some defect of the conformation of the sinews tending to weakness, such as an improper 
contraction of the volume of the leg, below the fore knee, and showing an insufficiency of the splint bone. These malformations will become hereditary. If a horse shoult break down in his fore legs, the breaking down itself may be said to have been hereditary; and no one should think of breeding from such a horse.

The following rules may be adopted:

First. There is economy in buying and owning horses of value.

Second. The more blood the better; for the high bred animal has greater health, strength and quickness, and vigor of constitation, as well as gameness.

Third. The blood should always be on the side of the male; and that means, that the stallion should be of purer blood than the mare.

Fourth. Never choose a stallion that is not well ribbed, short backed, long below, and short in the saddle place, with the withers high, chest broad, a well set head, a bright eye, small ears, and broad loins. His hind legs above the hock and fore legs above the knee, should be long and muscular, and below these joints, short and bony. The bones of the legs should be large, flat, and free from excrescences-the sinews straight, clear, and hard to the touch. 


\section{CHAPTER SECOND.}

THE CHOICE OF MARE IN BREEDING.

This is a subject that will bear careful consideration, as good judgment must be exercised in picking out the mare from which to breed; as in a great measure the health of the foal depends altogether on that of the dam. Like produces like, and the best rule to follow is, blood from the sire, and beauty from the dam. Medium sized mares have a stronger constitution than very large ones, and on that account, they are the best to breed from. "The greatest blessing in life is an intelligent wife or a mare that produces foals." So spoke the prophet Mahomet, and in this speech there is a deal of wisdom; for a mare that brings forth foals, adds wealth to her owner; and she must not only be intelligent, but also be possessed of a good temper, good health, and plenty of room. The mare should be so formed in frame as to be well able to carry her offepring, and capable of nourishing it afterwards. A mare with a level, straight hip, in which the tail is set on very high, should never be selected for breeding purposes; but on the contrary, a mare, whose haunch bone forms an angle with the sacrum, is the one to pick from, because such a mare has room enough to allow the foal to pass out, and into the world. These points are very important, for if the foal is injured in the birth, it will never recover its powers, and will always remain injured. The pelvis should be deep and wide, and thcre should be more than the average length from hip to shouldcr, so as to give plenty 
of room for the foal. Beyond this roomy frame, the mare only requires such a shape and make as is adapted for the purpose intended, to wit: producing colts of the form and style she is intended to produce. To all this, she must have four solid legs, well shaped, large feet, and by no means flat soled. She should have a lean, bony head, small ears, broad face, well carried neck, high withers, and above all, long sloping shoulders. There is nothing more horrid than a straight shoulder, for it makes speed impossible, and gives a motion that often produces stumbling.

She should have a wide chest, and be very deep in the location of the heart. She should be very strong in her quarters, well let down, and sickle shaped above the hocks. If her hocks are wide. apart, so much the better, for it indicates power. It has already been shown, that a brood mare should be considerably longer in the back, than one would choose a working horse to be; and if she is particularly so, then put her to a short-backed and close coupled horse.

The brood mare should be as near perfect as the artificial state of the animal will allow ; and in every case, the mare should be examined carefully to discover what she has inherited from her ancestors. Barring accidents, all deviation from a state of health in the mare may be looked upon as transmitted to her; because, in a good constitution, no treatment, such as training, will produce disease ; and the appearance of any disease, under this process, will show clearly that it is acquired and handed down from her parents. Still there are diseases which should be excepted, or rejected accordingly. Broken knees, dislocated hips, and all such caused by accident may be overlooked; but spavins, ringbones, splints, and all bony enlargements, are defects transmitted, and will be sure to be perpetuated. Curby hocks are hereditary, and ought to be avoided. Bad feet should be avoided, unless when caused by bad shoeing; and in the latter case, it can be looked over.

Mares with broken wind rarely breed, and of course are out of 
question, as no one would risk the recurrence, even if such a mare. could get in foal.

Blindness may or may not be hereditary; but in every case it should be looked on with suspicion. Cataract without inflammation runs in families without a shadow of doubt, and when a mare has both eyes suffering with this disease, without any other derangement, it is best to let them pass. If blindness is brought on by cold, accident, or violent inflammation, the eye is more or less disorganized and although this is objectionable, still it is not as bad as regular cataract.

Under no circumstances breed from a stallion which has any affection of the respiratory organs, or from one that has any affection of the eyes, unless it be the result of accident, such as a blow, or puncture would produce,-nor even then if one eye sympathized with the other; and on the other hand, breed not from a mare that is affected either way.

Before sending the mare to the horse, she should be got in a perfect condition, by plenty of good nutritious food, gentle exercise, and comfortable stabling. She should not be in a pampered state, caused by hot stables or heavy clothing, but instead, her coat should be short and fine, and the skin should be in a glowing and blooming condition, just like what we would expect to see in a racehorse just before a race-not that she should be in that wiry form training produces. She should not be overloaded with fat, especially that kind of fat which artificial feeding produces. During the first three or four months of her gestation, while carrying the foal, it would be well to let her do her regular work; but she should not be compelled to gallop long distances, or put to any sudden or extreme exertion, such as pulling excessive loads, or in any effort likely to produce sudden strains, which of all things is the most likely to cause the mare to slip her foal. As time wears on, her work should be lighter, and her action slower, but at the same time, her exercise should be regular. 
If she is allowed to run in the grass, she should be put in a small enclosure, which will not be large enough to admit of her galloping at racing speed, because she is liable to fall in running, and this would produce disastrous consequences. The enclosures should have fences high enough to keep the mare from thinking of climbing or breaking through; for if the fences are low, the mares will be continually trying to leap them, or force their way through, and then in all likelihood fatal accidents will occur. It would be better to have the fences made so, that at the upper part, the work would be open, and then the animals in adjacent lots would see and communicate with one another without being able to r ach each other. When so situated, they will be on a constant trot, trying to get together, and this gentle exercise will afford them good.

One acre of ground is sufficient for such a pasture, and on it should be built a substantial shed or hut, which will provide shade in summer, and warmth in winter. The entrance should be five feet wide and eight feet high, the edges of which ought to be rounded off, so as to keep the animal from injuring herself in going in or out. During gestation, the food of the mare should be generous, liberal and nutritious, and at the same time, not heating; for it must be known that the mare has, during this time, to generate blood to nourish the foal she is carrying, and to nourish herself.

Large quantities of oats or corn ought not to be given; but instead, clover, green corn cut young, and above all things, carrots should be given in abundance; and bran mashes, with from four to eight quarts of oats, can be given with advantage daily. It is almost a certainty that if the mother is starved, or fed on improper food, or kept cold, or wet, or exposed to the weather, the foal will be a scrawny, undersized, poor, half-starved looking wretch, that had better never seen daylight. Care should be taken of both after the foal has becn dropped, and nutritious food of all descriptions should be given with a liberal hand, and it will pay to do so. One thing, which is important, should be looked after in selecting a mare for 
the stud, and that is, the temper of the animal; for a vicious rogue should never be the mother of a colt; neither should a mare be used for this purpose, that won't answer when called; or one so stubborn and contrary, that it is impossible to train her, for such a one is even worse than none at all. The following rules will serve every purpose in selecting a mare for the stud. First. Beauty, soundness, temper and size, are best regarded in the mare, and blood in the sire. Seoond. Her frame should be roomy, with sloping hips, broad chested, deeply girthed, strong quarters, and well let down, wide apart hocks and deep in the pelvis. Third. She should be courageous and free from all viciousness. Frourth. Before going to the horse, her condition ought to be perfect and not overloaded with fat. Fifth. She should be fed liberally with nourishing food that will not overheat her, and for the first three or four months her work must be moderate, but her exercise must be regular. 


\section{CHAPTER THIRD.}

THE PROPER AGE TO BREED FROM.

The general opinion among breeders of horses is, that a mare must be at least three years old before she is put to the stud; and the horse must be fully matured; but nevertheless have been known to commence breeding when two years old, but their progeny never lasted any length of time. An old stallion and an old mare will produce like results, but an old mare and a young horse have been known to get the best horses on the turf; as for instance, Nina, the property of Major Doswell, of Virginia, in her twenty-lifth year gave birth to the celebrated colt Algerine, and since then she dropped Algeria, a full sister to the aforesaid horse. Nina is still living, and in her twenty-ninth year was stinted to Abdel Kader. Then again, Flora Temple dropped a colt when very old; showing that the mixing of young blood with old will produce good results. Age is no bar to success, if matched with youth on the other side. When a young mare is chosen, the horse should not be less than ten or twelve years old; but they never should go together when of the same age. It is all a mistake to say that the first produce of a mare is her best, for there are many instances to prove to the contrary. Take Nina for example; her first colt, Planet, was a stunner, and her last colt was a good winner, while her filly is spoken of in the highest terms. Crucifix was dropped when his dam, Octaviana, was in her twenty-second year; and the celebrated Lottery first saw the light when her dam was in her twentieth year. With 
these examples before us, it is safe to say that some mares will breed as long as they live.

\section{IN AND IN BREEDING.}

What is understood by this is, the mating or pairing of relations in blood within the degree of second cousins; and a great deal can be said both for and against it. Following the law laid down by human nature, it seems unnatural for relations to become united, and is said that such unions produce abortion; but then, again, in newly settled countries, this in and in breeding is carried on to a great extent; because the settlers need stock and are not very particular about mixing the same blood; and horses in their wild state are known to cohabit with their offspring until driven away by the younger and stronger horses. The mustangs of Texas have not changed in their size, condition or appearance; and it is a wellknown fact that they have no respect for the religious law of selfdenial when in company with their own kindred. When the Arab was first introduced, and his value as a getter of race-horses became known, there was no quibbling, but in breeding became so very close, that it almost became incestuous; and it was this kind of breeding that gave us our present race-horse. So, in fact, although forbidden by divine law, there is really no harm in it; but on the contrary, a great deal of good, providing the blood is pure. 


\section{CHAPTER FOURTH.}

\section{THE PROPER WAY TO CONNECT SIRE WITH DAM.}

The advantages to be derived from breeding to pure blood on the side of the sire, no matter what the quality of the dam is, has been already shown; and we will now show the improvements to be gained in various varieties, and what will produce this improvement; for it is dead certain, that the same kind of horse will not answer for every mare; for to produce an equality in progeny, it will require sires of very different styles, for mares of different styles. The object of breeding are two-fold, one of which, and the most common is, to breed from cold blood; for example, the Conestoga mare, or the large Vermont draught mare, to raise a stock of horses from that will stand fatigue, be light of action and speedy of foot, by crossing that blood with thoroughbreds. This is the easiest thing accomplished, for any such horse will certainly make an improvement in the issue of the dam; always providing that both are in a sound condition, and free from all vice. The progeny of such will, in blood, structure, form and spirit, be a vast improvement on its dam, and so much so, that the old lady will hardly know her offspring.

In the third and fourth generations, when the blood has become thoroughly mixed and an improvement in the stock is visible, it will then be the duty of the breeder to look to other families, and other strains of blood; for it is well known that the more distant the blood, the better it will cross. It must be always borne in 
mind, that the stallion should be a thoroughbred whose family is noted for courage, and a good stout frame, and that he has no defects of form which has already been alluded to. It is altogether wrong to put small mares to large horses, or immense mares to ponies, for there ought to be an equality in size and form; or else the produce of an ill-matched pair will result in an ill-formed and ugly specimen of horseflesh. A mare of sixteen hands high should have for a consort a stallion not less than fifteen hands high, and in proportion as they get higher. A mistake is often made in putting little mares to tall horses, or low mares to a horse all legs, in hopes of giving height to the issue; for the way to give size, is to select a horse of perfect form and one not much higher than the dam; but it will make no difference if one or the other is an inch or two larger, provided the stallion is not too long in the legs, and more especially from the knees down, and more particularly so if the mare is defective in these points.

Where both are defective in any one and the same point, or "even undeveloped in that particular point, it is the height of folly to couple them, in the vain hopes of seeing every defect banish in the offspring. There has always been a difference of opinion in regard to which the progeny takes after, in color, health and size; one authority saying that there is no rule to go by, and the other asserting that while the dam glves health and constitutional powers, yet the sire furnishes general character and external appearance. Now, the better way to look at it is this: Whichever is the best blooded and nearest a thoroughbred, that will be the one, whether it is father or mother that the progeny will take after. It has been already asserted that a blooded horse put to a common mare improves the stock; and the improvement comes from the one having the best blood; so it must be again said, that the progeny will be nearer a true likeness of the good blood, than of the cold, poor blood.

When a mare is slightly defective in any one point, it will be best 
to select a stallion that is excellent in that particular point; and when a breeler falls in love with a stallion, on account of his beauty, former performances, or blood, and that horse is weak in any one or more points, it will then be best to put him to a mare who is strong in the points where he is weak; but on no account must be be put to a mare having the same faults as himself. Where mares, possessing some degree of pure blood, have degenerated in size, strength and height, then it is best to breed them to such a horse as will improve them in size and bone without injuring the blood; but first of all, it must be ascertained in which the impure blood exists; and this is a very difficult thing to do; but, should the blood be cold, such as is found in common cart horses, then it is of no possible use to bother with it, as the result will not * pay. But if the blood be pure, and the stock have long been in bred, then the best possible way to do, is to stint the mares, to the best thoroughbred stallion that can be found; but he must, be short legged, wide chested, strong loined, and of a strain of blood entirely distinct from that of the mare. The stallion should not be any taller than the mare, but must be stronger and show more muscular development. In the second generation, the offspring will be larger, in every way, than their dams, and in health, strength and outside appearance, there will be a decided improvement. This may be repeated by putting the fillies of that dam to horses of exactly the same kind. This in the end will prove profitable, and is what is known as breeding $u p$, and if followed up as advised, at no distant day the breeder will have animals that anybody would be proud of. Crossing and re-crossing of stock often produces wonders, and when succesful for a great many years in any one line, it is called a "hit," and does not depend altogether on the advantage of blood, but on something so mysterious, that no one can find out.

There is no possibility of prophesying what blood will or will not " hit," but there are facts, connected, which will cause the breeder to think and find out the reason. The habits of horses, oxen and 
other animals are well known in their wild state, and that they will copulate with their daughters and granddaughters there is no shadow of doubt; and this in breeding has caused some of the best strain of blood in America. Then when it becomes known that persistent in and in breeding has caused degeneration, or any other evil results, the next best thing to do will be to look afar off for a different strain of blood, which when crossed, will produce a more healthy and vigorous offspring.

The following rules will simplify the grounds taken above. First. Mutual adaption, between sire and dam, in size and form, is very important and should be adopted. Second. Where one is defective in any particular point, do not breed to another having the same fault. Third. Keep very small mares away from very large horses; abortions will be the result of such speculations. Fourth. Where it is known that the blood of one family of horses will not cross well with another, avoid it; and let there be no connection between two such horses. 


\section{CHAPTER FIFTH.}

\section{CANADIAN NORMAN BLOOD.}

This breed of horses are a distinct family, and very valuable as a working horse, and as a sire or dam. Where found in a pure state, and not crossed with our American thoroughbreds, he is without a doubt, the French Norman horse; but in their present state, as we have seen them in Canada, their head is rather large, but lean and well formed, with broad forehead, ears far apart, a small eye and full of courage; a full chest and a strong shoulder; and above all, having the soundest legs to be found on any race of horses not thoroughbred, and with feet like iron; and it makes no matter how badly they are shod, or what hardships they undergo, their feet are proof against founders, and all other diseases of the foot.

The prevailing color of the Canadian is black, and brown comes next; after these come chestnnts, duns and sorrels, with tails, manes and legs of a color lighter than the body; and last of all are the dark iron-greys, with black legs. The genuine Canadians are remarkable for thickness of manes and tails, and also for the wavy, curly texture of the hairs,composing them. The Canadian generally measures from fourteen to fourteen and a half hands. It is seldom that une is found that is speedy, and their best rate is six or seven miles an hour; but they can pull a heavy load, and can easily go fifty miles a day under that load without tiring, and some of them have been known to go ninety miles in a day. The only instance of a fast or speely horse appearing among them, was the celebrated trotting stallion St. Lawrence, who was well known in 
years gone by ; and it is a singular fact that no attempts have ever been made to improve that stock among themselves, although many of them have been improved by crossing with other races. As their excellence is generally acknowledged, both as a draught, and farmer's working horse, and as brood mares, from which could be raised a useful working roadster, by breeding them to blooded horses, it is singular that breeders do not pay more attention to this subject. The easiest way to improve this stock is to select the largest and most shapely mares of that breed, and then select the best stallions of that breed, always remembering the rules already laid down, and to see that the mare is in prime condition before putting her to the horse. During the mare's pregnancy, she should be liberally fed and comfortably sheltered, though not to force either mother or foal by hot lodging, or too stimulous fond ; and, in the course of a few generations, a couple of inches will be added to the height of the Canadians, while their former merits of bone and sinew will be improved upon.

They are the only horses of cold blood that it would be advisable to breed on both sides; that is, either each to each, or each to other, for the improvement of their own and other foreign strains. By breeding the improved Canadian mare to a well-selected thoroughbred, a highly improved light carriage horse or a good roadster will be the result; and by again breeding the filly produced by this cross to a thoroughbred, there is no doubt but what the best saddle, or light carriage horses in the world can be produced, and all resembling the Morgans, but stperior to them in every respect. Norman and Canadian stallions are the only horses that ought to be put to light American blooded horses, because they can be made to produce a progeny, improved in every respect, and better adapted to become the mothers of large carriage horses, by breeding them to Normans, either native or imported. The Normans, though small themselves, when crossed in either way, generally breed larger horses than themselves. 
THE PURE NORMAN.

The Percheron Norman horse, of which a great many have been imported of late years into the United States, originally belongs to Le Perche, a district of France, that was formerly known as Normandy, where the improvement of the horse was cultivated in the highest degree; and indeed the remarkable purity of that family is vouched for in the certainty with which either sire or dam transmits its own likeness and character to its offspring, no matter if even coupled with horses of a superior or inferior blood; thus proving, that like begets like when the blood is pure.

If a pure Norman mare is bred to a purer blooded stallion, the marks of the mare will descend to her foal with very little alteration or modification.

Without being considered a thoroughbred, the Norman may be looked upon as a pure race, and a race that can breed in and in without altering or injuring their descendants in any way, just as prize cattle, setters, pointers, greyhounds, and all other perfect animals do. This family of horses measure fully sixteen hands in height, with a short thick head; hollow and wide between the eyes, heavy jaws, short ears, short thick neck, heavy mane, extremely short back, steep rump, broad quarters, wide chest, large tendons, well developed muscles, short legs, and much hair all over the limbs. In France, the males are never castrated, and there is wisdom in that fact, for the farmer will always breed from the best horse, having a good opportunity of judging which is the best, as they are all broke to harness, and the horse's qualities are well known before he enters the stud ; and here let me say, that it would not be only a good idea to follow in our country, but it would be a natural one, as nature never intended that any living thing should be deprived of half its life, or else they would be born in that way; and then, again, as farmers well know, the horses that are gelded very often turn out better than those who are kept 
for the harem, andi it has often been said: "I wish that I had never cut that horse."

This idea of the Norman people is one of the causes why our race-horses are preserved, if not improved; for unless very vicious, we do not deprive our thoroughbreds of the means of generation, and, therefore, the breeder has all the males to pick from, instead of having only a few from which to select, and by this time he knows which is the best. In my opinion, a general law should be passed which would read something like this: "Any man caught in the act, or known to deprive a colt of his sex, must suffer in like manner." This would put a stop to a barbarous practice, and make everybody obey the law of our common maker, and at the same time benefit the breeder in many ways.

The horses of Normandy have more endurance and energy, and can work harder, with less food, than any race of horses living; and they can keep their condition under brutal treatment when other breeds would die. No better stallion can be had to cross with our light American mares; and we hope to see the day when more attention will be paid to this particular style of breeding. 

in a corresponding degree, and all owing to the want of care and intelligence in the owners of those once grand and valuable horses. On the other hand, the descendants of those very same horses, on American soil, have vastly improved, because they are better housed, and, in fact, are attended to by men of intelligence, who have improved in their method of breeding, and who know enough to improve their own interests.

A cross between the Arabain and the Canadian, or Norman, might be advantageous, but at present we feel inclined to think that the modern Oriental is greatly overrated.

\section{CHAPTER SEVENTH.}

WHAT CAN BE SAID ABOUT PONIES.

In ancient times, ponies were rarely spoken of; but in the nineteenth century, we, who inhabit the earth, ought to know them pretty well; for indeed there are some which are as beautiful and docile as they are lovely, while others, like the Indian ponies of the North-west, and the war-horses of the Apaches and Comanches, on the western reserve of Texas, are as wild as March hares; but when the latter are captured and trained, they are as quiet and obedient as one would wish. I know an instance where the attendant of the now celebrated trotter Rarus, bought a pony, in Dallas, Texas, for twenty dollars, and taught him to actually trot. Bringing that pony North, the owner captured many a shekel while on his way from Dallas to Brooklyn; for everybody knew that the canter and gallop was the natural pace of the Indian pony ; but nobody ever dreamed of one trotting.

The Mexican and Texan mustang are similar, and are undoubtedly of Moorish blood and origin; but how they ever got into our 
Southern border State has been, and will always remain a mystery. They run from thirteen to fourteen hands high; their limbs are very slight; and their shape-well, it is no shape at all; but they have long lean heads, fine manes and tails, and in their wide nostrils show pure blood running in their veins. 'It is said by an authority, that they lack hardihood and endurance, but this is a mistake; as I know from actual experience, that they will travel night and day, without rest, providing the rider will allow them to nibble the prairie grass, and give them a generous supply of water, when crossing a stream; and aithough they are not what would be called fast travelers, I will state, without fear of contradiction, that they will outlast any horse on American soil, for there is no tire in them, and, like the Norman horse, they do not fret at being ill fed.

From what we have seen of said ponies in Austin, Texas, and west of it, we have a high opinion of them for their staying qualities ; for their easy carriage ; and above all, for their faithfulness, and their instinct in scenting danger afar off; as we well know.

People who are fond of special colors will have no difficulty in pleasing their taste, provided they go to western Texas; for they are of every known color ; even uuto piebald. Our constant companion and faithful friend, during our pilgrimage through Texas, was a bright bay filly, and the recollection of her goodness will never fade from our mind.

The Indian pony of the upper Mississipi is an entirely distinct animal from the one already described; and just as much so, as the Comanche Indian differs from the Sioux. He rarely runs over thirteen hands, and is compact in every particular, and having feet similar to the Canadian horse-all iron. A mule is not any more sure footed than this pony, and they will jog along at their leisure for a whole day under a saddle, or drawing a heavy wagon, without a murmur. They are as quiet and intelligent as their kin in Texas, and their courage is proverbial; and there is no 
doubt but what they could be improved upon, by prudence, patience and good treatment.

\section{SHETLANDS AND SCOTS.}

The most remarkable of European ponies, and the ones most highly prized for the particular use made of them, are the Shetlanders, which do not measure over nine or ten hands. The shape is round, with a coarse mane like a lion; a lean bony head, and handsome. The ears are very small, lofty and well placed; and having clear, intelligent, and very large eyes, and their legs and feet are matted with hair, similar to the Normans and Canadians. A luxury to them unknown, is oats, but a bundle of wild hay or barley straw is a feast to them. They are not noted for speed, but vill pull a couple of hundred pounds with ease, and travel at the rate of five miles an hour; but in reality, they are only fit for boys and girls to ride, and in that sphere they are at home; and yet they are very tricky, and like the ass, will throw their rider over their head once in a while, and then turn round and laugh at the unfortunate victim; but will remain standing, until semounted, and await a favorable opportunity to repeat a trick. All colors abound, except white and gray, which are very rare, and black is considered the best.

There are no descriptions of ponies more worthy of particular notice than the Galloways and Narragansetts; and, in fact, they ought not to be called ponies, for they are really a connecting link between a horse and a pony; and in Ireland are commonly called "Cobs." The one was from Galloway on the coast of Scotland, and the other from Galway, in the west of Ireland; and the two were so similar in appearance, habits and docility, that although they were separated by a wide sea, they were one and the same thing.

In the first named place, they were noted for their speed, endurance and easiness of gait, and were highly prized for saddle purpo- 
ses; but the breed is now extinct, so far as Scotland and England are concerned. Across the channel, however, the case is different ; for they roam in a semi-civilized state, as the poverty of the farmers, and the wild rudeness of the district of Galway, allow them to be as wild as our own western ponies. There is no doubt but that they descended from Spanish horses; for in the fourteenth and fifteenth centuries, Spain and Galway were intimately connected by commerce; and it is not only in horses that the blood of the Spaniards can be traced, but also in the people of Connaught, the traces of Moorish blood can be seen even now. And then, again, when the Spanish Armada was wrecked on both coasts, the Spanish ships were full of cavalry; the horses, no doubt, saved their lives by swimming ashore, while their masters drowned; and thus adding something new and valuable to the empire of Queen Elizabeth. In endurance they are equal to our Texas ponies, and it is a pity that such a fine breed of animals should become extinct, for really they are worth preserving. As they are a pure race, of rare powers, we would suggest that some noted breeder would look into the matter, and rescue those splendid animals from the wilds of Galway, and breed a race of American "Cobs" that would become very popular in the course of a few years; for no better saddle horses ever existed, and, as for docility and endurance, none can equal them except our own Indian ponies; and the two together would make a splendid race of animals. 


\title{
CHAPTER EIGHTH.
}

\author{
HINNIES AND MULES.
}

Everybody knows that the mule is a cross between the ass and the horse; but how many are there that know the difference between a hinny and a mule? They have no idea that the two animals are distinct, and yet both are the offspring of the horse and the ass. But which is which ; and which is the other? Can all of our readers answer this question before wading any further into this chapter?

I remember once seeing a negro in New Orleans use every effort in his power to make one of those stubborn brutes rise from the ground, where he had laid down, determined to stick it out if it took all summer. The day was very warm, and I stood laughing when Sambo would use his eloquence on that champion lyer-down; and would condemn him when he used his rawhide unmercifully. But, to tell the truth, the darkey gave out first. The poor brute took all the beating without a murmur, and when the darkey got tired, the animal kind of smiled at him, which made him wax eloquent, in the following words :

"Now, you dog-gone mule, you's got puttin on airs with dis chile, 'case he is a darkey, and all de time you's a forgettin dat your fader was a darn jackass."

Now, to tell the truth, if that colored gentleman had any money I would have won it from him on the spot, by way of punishment; but as he had none, I approached him, saying: 
"Uncle, the father of that happy creature was not a jackass; and, another thing, he is not a mule."

"Good lor, massa, if dat ugly reptile is not a mule, then he is the debbil ; but he's sure to be fixed when I cotch him home ; and now he can lay dere just as long as he likes, for dis chile can stand it as long as he can."

I did not give him the necessary information, because it looked like so much knowledge thrown away, but left him in doubt as to whether he was driving a mule or a devil. It is unnecessary to state that he was not driving either, for, in fact, it was a hinny.

I have no doubt but that there are a great many people in the same fix the darkey was in, and I will now tell them the difference.

The offspring of the male ass and the female horse, is surely the mule, without a shadow of doubt. The offspring of the male horse and the female ass is the hinny; and the surest way to distinguish between the two is, the hinny neighs, while the mule brays. And this is not all; for while the mule has all the external resemblance of the ass, the hinny bears a more striking resemblance to the horse. Now, if we examine a little further, it will be seen that the mule has the temper and beautiful character of the ass in his nature; and the hinny more of the horse. By a knowledge of these facts, which are full proof, the breeder is led to insist that the sire gives the greatest excess of blood and energy, and that he invariably finds that, whether the mare be the most wretched one in existence, or a thoroughbred equal to Peytona, when the sire is a jackass, the mule of the ass type is the consequence.

The hinny has a small, well formed head, the full tail, and flowing mane; the form, feet, legs, and voice of the horse; while the mule has an almost hairless tail, with ears slightly modified, slender legs, and the voice of the ass. What appears remarkable is, that the offspring of the male ass and female horse is generally a larger animal than that of the stallion and female ass, and very often larger than either of his parents. 
The mule which has for its sire the male ass, has all of his qualities-the patience, endurance, and faculty of keeping himself in good condition where a horse would starve; and the sure foot of the ass, with his tempcr, stubbornness and vice; while the hinny is hardier, more patient, and better able to stand privation than the horse; but is inferior in all those qualities to the ass and the mule. At the same time, he is more gentle in temper, and nearer the horse in all his characteristics. Both the hinny and the mule are modified asses, as they both have more of the ass than the horse in them; but that proportion of more. depends altogether on the male, and not on the dam.

It is quite clear that in all hybrids of the horse and the ass, the latter gives the greater proportion of internal and external character; then, if we are breeching mules, on the courage, temper, and spirit of the he-ass, all will depend in the like production of the progeny-while, if the mare is sound and roomy, it makes no matter whether she is a mare pulling an ash cart or a pure thoroughbred.

If it is hinnies we want, we must find the best stallion, in blood and bone; while in the female ass, all we may look for, is soundness and size enough to give her room enough to contain a foal larger than her own progeny, as the himny is likely to be. It is our opinion that the hinny is as good as he is handsome, compared to the mule, and superior to the latter for saddle purposes; but being inferior to the horse for that specialty, and inferior to the mule as a beast of draught, he unluckily has no place of his own, and therefore he has got a bad name and nobody will cultivate him.

Mules are more largely bred in the United States than in any other country, if we except South Amcrica ; and, as beasts of burden, they are infinitely superior to any other animal. He can carry twice as much as the horse, if not hurried, and keep himself in good condition where the horse would starve; and he will last twice as long as the average of horses. This will be an inducement to breed the mule, and to use him where he is best fitted. 
Asses are not bred to any great extent in the United States, the majority of them being imported, and it is of the greatest consequence that the proper jacks should be selected for the purpose designed. It is well to observe, right here, that the work of the mule will ever be in the field, and team draught on the road; and in the far west they will be used as pack animals.

While we try to raise the largest mules possible, thinking they are the best, the fact is, that the smaller animals are greatly superior for all the purposes intended of them.

There are three different varieties of asses from which to breed; the first of which is the Spanish jack, which gets mules for farming purposes. The next is the Andalusian jack, a degenerated descendant of the Arabian species; sprightly, high-spirited, and sufficiently strong for every purpose; and the last is the Arabian jack, which stands in the same ratio to the ass, as the thoroughbred does to the horse. To breed from any of the aforesaid jacks, a mare standing fifteen hands in height, is sufficient stature; but they should be roomy, long-bodied and bony. Well-selected Canadian or Norman mares will prove to be the best mothers of mules, and thoroughbreds will always prove to be the worst; and all that remains to be said is, mules should be handled as young as possible, and then they will become gentle and lamb-like. 


\section{CHAPTER NINTH.}

\section{POINTS IN HORSE BUYING.}

To become a judge of horses, one in whom confidence can be placed, and whose word is authority, it will be necessary to serve half a lifetime in the close study of the anatomy of the animal; and even then, there are some who know no more than they did when they first started. There is a knack about it, that comes as a gift, and this natural study and judgment of horseflesh is worth more than a man can learn in colleges during the whole space of his life. Still, there are persons of intelligence who remember what they have read, and they are not often deceived in matters of that kind, although it must be admitted that they are not thoroughly posted. The amateur who wishes to buy a first-class horse for his own use, and who does not pretend to be a judge of the animal, must never buy at a horse fair, nor attempt to buy out of the breeder's hands; but, instead, he must buy of some one whose character is above reproach, and who has some honor to lose. This kind of a dealer will try to get all he can for his horse, but it is very unlikely that he will deceive the buyer, for his reputation for fairness and honesty is at stake, and doing wrong once might ruin him.

It is very often the case that breeders do not actually know themselves what their horses are, in regard to speed and soundness, having, perhaps, never tested the animal offered for sale; but, by buying of the breeder, you may be pretty well assured that he believes the horse to be right. It is almost a certainty that horses 
in the bands of the breeder are never properly trained, and, unless the buyer is a perfect horseman, it will cost as much more to have the horse properly trained, before he can use him with safety.

Never imagine that perfection can be bought for a song, or that cheapness ever got a good horse, for a good bargain is always suspicious, to say the least. If the animal offered for sale is very superior, has a showy appearance, a fine style of action, and the price asked is low, it is morally certain that such horse has a very bad fault, which time will surely discover. It will be always better to give the seller more knowledge than you possess, for he is aware of what he is doing, and you are guessing. Always pay a good price for a horse, taking a written guarantee that he is sound in wind and limb, and free from all blemish; and then you will not likely be deceived, for everybody, horse dealers included, is shy of the law.

Farmers' horses are the least difficult to buy, and the saddle horse is the hardest to select. The best points to judge a horse from, is his legs, for if they are bad and all the rest lovely, then he is worth nothing. The age and eyes are next to be looked at ; and as to the former, up to his seventh year, the marks in the teeth of both jaws plainly tells the number of years the animal has lived. The lower jaw varies every year until the eighth, when the marks go out of use.

The jockeys have a rascally system of forging false marks on the teeth of horses that are aged, often making them appear five or six years old, when in reality they are eight or ten; and is so deceiving, that sometimes old hands are caught in the trap. This is done with a file and the usual cautery; but with all this, there are some signs which cannot be removed, and are easily recognized by anyone well posted. In a young horse, the crown of the tooth is oblong in form, lengthwise, or in the line of the jaw bone; but in very old horses, the crowns change their shape, and become oblong across the jaw bone. 
Whenever the tooth has taken this form, or has become modified from the lengthy shape, it is dead certain that the horse is too old to be valuable. Another sign, is the length of the teeth from the crown to the root, looking like those of the hare or rabbit; and the increase is regular with the increase of age. A buyer should always look to the points mentioned, as what one seeks to avoid is extreme age, not maturity, or even the beginuing of decline. It matters little to a racing man whether the horse he buys is eight or nine years old, providing he is sound, and free from the effects of wear and tear; but always remember, never to buy a horse under six, if required for hard use; and if the animal be sound, and clean in the legs, it would be better to buy at eight or nine years old.

Next to the legs, the eyes are the most important, and in which imperfection is often hard to detect, as there are some kinds of blindness which give no sign. While examing the eye, the horse should be in the stable, standing a little within the door, but never in the open air. The cornea is a perfectly transparent coat, placed in front of the eye, and inserted like a watch glass; and if any whitish lines seem to cross it, they are signs to tell you of previous inflammation. If the centre and bulk of the cornea should be perfectly clear, and the edge around it should have a ring of haziness, then the sign is true; but the inflammation is not of a recent period; but nevertheless it is likely to return. A simple way of detecting anything wrong about the sight, is to hold the horse by the headstall, and after caressing him gently, so as to avoid alarming him, stand in front of the horse and move the fingers rapidly towards and across his eyes, carefully noting how he winks or starts; but care must be taken not to create a current of air by moving the hand too quick, for that would cause a horse that was totally blind to wink and start back, just as if he could see.

Next to the eyes, the condition of the lungs must be looked after, and this requires a careful examination; and where one is found with any complaint of this sort, reject him on the spot, as 
such disease is never cured. This malady is caused by the rupture of one or more of the air cells of the lungs, and the loud, sobbing breath, heary heaving and jerking of the flanks, tells the story. There are jockey tricks which will cover this disease for the space of three days; but let the horse be galloped a hundred yards, up hill, and then let the rider spring quickly to the ground, and, putting his ear to the chest, the double expiration will be heard, even if the flanks do not move. Want of space in the lungs produces "thick wind," and the exertion in trying to breathe often leads to suffocation. Whistling, wheezing and roaring are modifications of thick wind; and any animal subject to any one of these complaints will soon become exhausted, and, no matter what the form is, it will finally end in broken wind. All of these diseases are easily detected, for by catching the horse by the throat, he will be compelled to cough, and if sound, will cough only once, and then recover; but if unsound, his cough will be broken, ragged and rattling, and he will recover his breath with a long, laborious effort. By hitting a roarer a sudden slap on the belly, he will utter a loud grunt, and, when roaring becomes chronic, speed will bring it out; but if he only whistles, the best way is to pull him up suddenly after a long gallop, and, bringing the ear close to the windpipe, the whistling will be heard for many seconds. There is no point in a horse in which an amateur is more likely to be deceived than in wind, and it will require the greatest caution to be able to find it out. 


\section{CHAPTER TENTH.}

\section{HINTS IN REGARD TO THE LEGS AND FEET.}

There is nothing more fatal to the horse than the diseases of the feet and legs; for once a horse loses the power of traveling, he is useless, except for the stud, and even then he or she is worth but very little. The buyer should insist on driving the horse sapidly on a hard road, and if there is any lameness in him, it will crop out immediately. When white hairs are discovered in smyll spots, except on the face and feet, they are the signs of woun ls; and wounds of greater depth are often proven by bare spots, where the roots of the hair have been destroyed. If white spots are seen on the knees, it is morally certain that the horse has at some time or other broken his knees by falling; but this is nothing if it be healed, as it does not cause unsoundness. Still, a horse that has fallen once will, in all likelihood, fall again, and it is best to pass on all such.

When examining the legs of a horse, the buyer should stand with his face broadside to the horse, and see whether he stands with his legs straddled, or with all drawn under his belly, or stands with the natural proportion of his weight on each leg squarely, or whether he farors one leg more than another, by placing it in a position where no weight is thrown on it. A horse may, from accident or impatience, point a toe forward once or twice, but he should be instantly brought back to his former position, and if he is then found to favor the same foot, there will 
be cause for suspicion; and if it is the toe of the fore foot, it may be put down as disease of the coffin bone, which is almost incurable. If the horse has ever been foundered, he will show it by throwing both front feet forward and stretching the hind feet backward; and if he stands with all his feet drawn together, he is sure to be gone up. Should he bend his knees forward, and his legs become nervous, it is certain that he has been knocked all to pieces by hard driving or overwork; but if he stands squarely and truly, leaning his weight on all his legs, then it may be taken for granted that he is all right as far as his pins are concerned.

Curbed horses, or those having hocks curbed shaped, are to be avoided; but an old horse that has done his share of work without being curbed, must not be thrown aside because he has curby hocks; for if his early hard work did not bring them out, there is no danger that he will do so now. The purchaser must now stand facing the horse's head, and observe if the horse moves his legs regular without favoring one or the other, and see if he is knockkneed or bow-kneed, and if either, he is almost sure to strike one leg with the hoof of the other, a bad and often dangerous fault. Cat-hammed horses are those whose hocks are drawn in, and this is a sign of weakness. This examination being over, the buyer will look to the several legs for marks of unsoundness, such as splints, ringbones, and damaged sinews in the fore legs, and in the hind legs; bone, blood or bog spavins; curbs, thoroughpins and ringbones. These are the points the buyer should look at; but, even if he is a good judge, my advice is to never buy without a guaranty that all is right.

\section{THE WAY TO FIND OUT A HORSE'S AGE.}

There are two sets of teeth, the first of which is called the milk teeth, which come before the horse is one year old; and the second are permanent, which come after the former have fallen out, and this is completed when the horse is five years old. 
T'he nippers are the most uniform in their progression, and of these there are six; those farthest from the centre are termed " corner teeth." These corner teeth, and, in fact, all of the nippers, are made of a bony substance, inclosed in enamel, which gives hardness to the teeth. The milk teeth give place to the permanent set, in the following order : the middle nippers at two and a half to three years; the next pair at three and a half to four years, and the corner teeth at four and a half to five years.

When five years old, the corners are up even with the other teeth, the mark is entirely worn out from the middle nippers, and partly worn from the next pair.

When six years old, the mark is nearly gone from the second pair, and the outer edge of the corner teeth is worn down.

When seven years old, the mark is entirely gone from the second pair ; the edges of the corner teeth are worn somewhat flat, though there is yet a slight cavity in the centre.

When eight years old, the teeth of the lower jaw are worn entirely flat, the mark having disappeared from all of them. The surface of the tooth has become oval in form, and the central enamel is long from side to side, and is near to the front of the tooth.

When nine years old, the middle nippers are rounded on the inner side, the oval of the corner teeth and second pair becomes broader, the central enamel is nearer to the inner side, and the marks have left the upper jaw.

When ten years old, the second pair are rounded on the inner side, and the central enamel is very near to the inner side.

When eleven years old, the corner teeth are rounded, and the central enamel becomes very narrow.

When twelve years old, the nippers are all rounded, and the central enamel has entirely left the lower jaw, but it may be seen in the upper jaw.

When thirteen years old, the middle nippers commence a triangu- 
lar form in the lower jaw, and the central enamel has disappeared from the corner teeth of the upper jaw.

When fourteen years old, the middle nippers have become triangular, and the second pair are assuming that form. The central enamel has diminished in the middle nippers of the upper jaw.

When fifteen years old, the second pair have become triangular, the central enamel is still visible in the upper jaw.

When sixteen years old, all of the teeth in the lower jaw have become triangular, and the central enamel is entirely removed from the second pair in the upper jaw.

When seventeen years old, the sides of the triangle of the middle nippers are all of the same length; the central enamel has entirely disappeared from the upper teeth.

When eighteen years old, the sides of the triangle of the middle nippers are longer at the sides of the teeth than in the front.

When nineteen years old, the middle nippers become flattened from side to side, and long from front to rear.

When twenty years old, the second pair assume the same form.

When twenty-one years old, all of the teeth of the lower jaw have become flattened from side to side, their greatest diameter being exactly the reverse of what it was in youth. 


\section{CHAPTER ELEVENTH.}

\section{THE PROPER WAY TO FEED A HORSE.}

It is well known to those who thoroughly understand the horse and his habits, that his entire health, fitness for work, and, above all, his value, depends altogether on his food, the amount he eats, whether it is good or bad, and the punctuality in giving it to him at regular hours. I remember once in Washington, when Doctor Leiberman was lecturing me on account of my irregular habits of living, he actually compared me to a horse, which, at the time, I thought was horrid; but now I know that he was perfectly right when he said: "If I feed my horse to-day at twelve o'clock, tomorrow at two, and the next day at eleven, my horse will not pull my carriage, and so it is with you. To be able to live and keep up your condition, you must eat regularly, and if not, you will be like my horse-not able to pull." Careless grooming, wretched stabling, and ragged clothing is bad enough, but it must be said, that the evil most horses labor under, and the disgrace of most stables, is bad feeding ; and often when the owner is liberal in expenditures, and when nothing else is necessary, except intelligence, and a proper knowledge of the horse and his wants.

A horse should be fed according to his work, and before he sheds a tear at seeing the first light of day, his dam should not only be well fed, but properly taken care of. If to ill-treat them before the birth of the foal, and expose them to the sudden changes of the weather without shelter, and without food except such as the 
mare can pick up in the pasture, then the breeder need not be astonished at seeing an animal that ought never to have come into the world for very shame of its owner. "Penny wise and pound foolish" will never pay the breeder who undertakes it.

From the time of its birth, a foal should be treated according to its blood; and here be it understood, that no one expects a foal, the produce of a Norman, Canadian, or a cart stallion out of a common mare, and of whom it is expected to do nothing but drudgery all its life, ought to command the same attention and care that a thoroughbred should receive; but, nevertheless, it may be said, that if it is worth the trouble to raise any kind of colt, it is worth while to raise a good one; for to a man of feeling, the trouble is just the same.

As the foal is growing, he should be petted, and coaxed to eat of oats out of the hand, and after awhile he will take to them kindly, and like "little Oliver," will be crying for more. Then please him by dealing out every day in his little trough a quart or two, and increase gradually to a full peck, during the first year; and to two pecks added to his grazing in summer, and his chopped straw, hay, or other feed in winter, of his second year; will reward his owner ten-fold all it cost him.

A foal thus treated, at two years old, will be the equal of any threeyear old that is treated otherwise, and this, in itself, exemplifies the story about "penny wise." Any man who is fond of children will treat a foal, in the same spirit of kindness he would a child, and those who do not do it, look in their own light; and even with an ordinary foal this kind of treatment will be a hundred dollars more in the owner's pocket when the foal is three years old. Good food to the foal, and plenty of it, is like rain and sunshine to the flower, for both grow when kindly refreshed.

When we come to the working horse, and those that are supposed to be what is called fast working horses, give them more grain than hay, then watch the result. As for road horses, or a carriage team, 
from eight to ten pounds of the best hay, and twelve quarts of heavy oats, daily, is a sufficient allowance. On opening the stables every morning, the first thing that should be done, is to feed with a lock of hay and half a pail of water, and when the stables are thoroughly cleaned, aired and littered, and when they are neatly groomed, give them the other half pail of water and four quarts of oats, unless they are going out; and when they have nipped all this, indulge them still further with five pounds of hay, put in their rack, and let them remain dark and quiet. But should they have an early trip to make, give them six quarts of oats at their morning feed, but no hay. At noon, repeat the morning exercise, and after they return from their afternoon trip, they should be first cleaned, then watered, giving them the balance of the oats, and let them munch on the hay left in the rack until morning. This is diet enough, for oue day, for horses that do not travel twenty miles a day, and do that at their leisure; a few nicely washed carrots, given once or twice a week, will improve their coat, be of assistance to their wind and stomach, and they will show signs of gratitude to the donor. A handful of clover, meadow grass, young corn, cut young, will cool their blood and greatly please them, making them fond of the hand that's kind to them.

Medicine in man as well as horses is, as a rule, a humbug, for the more they get the more they need; avoid it if possible, and, above all things, drive quackery out of your thoughts ; if the animals do a hard day's work, and look played out from-over exertion, make them a bran mash, and pour a quart of good ale into it. This will do them more good than all the drugs in a corner store.

It will be found always best neyer to work horses for two hours after eating, for more horses have been ruined and foundered by being worked hard on a full belly, than from every other cause that can be put together.

The harder the work, the sounder the food, is the right motto 
for every owner to follow, and in this case, his oats should be multiplied, and his hay held back a little. Dry hay is injurious to the wind, but oats can be given with a free will to a game and hard worker. Moistening the hay and oats, and adding a little salt to their food, once in awhile, will be found to work well, as horses are very fond of salt and it gives their food a relish, and creates an appetite.

A great many horsemen have a fondness for nitre, and give it in the food, for the purpose of producing a fine coat ; but the wise owner will shun it, as finally it will injure the horse as much as opium injures the man.

Water is the horse's greatest blessing, and should be given to him in abundance, when he is cool and quiet, but never when overheated, or immediately before going to work, or after coming from work. If I were fitting up a stable, I should have a water trough in every stall, with pure water running through it all the time, and let the horse help himself at his leisure. Of course, when heated, jaded, or tired out, I would not allow him in the stall, but would place him in another where there was no water, and kept for that especial purpose. This theory may be excepted to, on the ground that the horse would drink too much and extend his stomach; but this objection I will answer right now, by saying, that the horse is more temperate, and less of a glutton than a man, for he never drinks unless he is thirsty, and when he has enough, he knows when to stop. To be sure, if water was allowed to lie in the trough, or vessel, it would become stale, and full of impurities, which would injure the horse if he drank it; but the noble animal is too particular about what he eats and drinks, and anclean water he would not touch. My idea, however, is to have a full continual flow of fresh, pure water, passing through a pipe, or in any other way that is convenient, which would supply all the troughs alike; and having a waste pipe underneath to carry off the underflow to some pond or cistern where such water could be 
used for other purposes. This could be accomplished at a small expense, and in the end the owner would be compensated in the health of his stock, and in enjoying the horse's enjoyment in being kept cool by the running waters, and in being able to keep himself without neighing or nickering for assistance.

In traveling long distances, for the first six miles of the journey, he should be driven at an easy gait, to aid his digestion; then his pace may be made more lively, until nearing his destination or feeding place, when he should be eased up, and allowed to end his trip a little cool. While traveling, the horse ought to be watered every ten miles, and this will not hurt him, if the trip is immediately continued; and a good rule would be to put a few handfuls of corn meal in the water, with a little salt added; and this will not only prevent a chill, but at the same time feel like a solid meal. Although horses are the most temperate animals living, whether of the human or brute creation, still they have never been known to join any Society; and when on a long journey, a cut of rye bread, steeped in ale, will do them more good than five quarts of oats; and perhaps they won't like it! Try them.

When traveling, even if it is inconvenient to yourself, remember the friend who is to obey your bidding, and carry you safely to the end of your journey. Have a little respect and consideration for him, and start at early daylight, and travel until eleven o'clock ; then rest until five, and drive until nine ; and at this rate, if treated kindly, and ioo much whip is not used, he will do his forty miles a day, for a month in succession, without injuring him in any way.

When the day's journey is ended, and the horse should look somewhat tired, give him some thick, luke-warm gruel, as soon as possible; and when cooled off, clean him well, giving him a bit of hay to play with; then properly blanket him, and bandage his legs, and after this is all over, give him his rations of 
water and oats; a good bed, and sufficient hay, and on the morrow, he will be as fresh as a daisy, and eager to continue the journey.

As said before, a horse ought to be fed according to his work; but no matter whether his condition be high or low, good feeding will pay in the end; and this point the reader can bet on.

\section{CHAPTER TWELFTH.}

\section{THE STABLE AND ITS ATTENDANTS.}

Our climate is so changeable, and the extremes are so far apart, that the importance of this question is undeniable. To be of genuine good, the stable, in summer, must be airy, cool and open, so that a continual flow of fresh air can pass through all day long; and in winter it should be warm, free from all draughts, except what is needed for ventilation. IIl vapors, and such like, arising from natural consequences, should be abolished by pure ventilation; and the horse should never be allowed to stand in his own litter, because it breeds what is called the scratches.

The light should be perfect, since it is real cruelty to animals to keep them in the dark, depressing their spirits, injuring their health, and very often causing bliudness. As horses are of a cheerful disposition, sociable in their manner, and full of joy when a known friend approaches, it is a shame and a sin to hide the light of day from them; for the Maker of all made the light, not for man alone, but for all living animals.

The best public stable, where eighty or one hundred horses are kept continually, I have ever seen, is in the city of Austin, Texas. The stable was built purposely for the comfort and health of the horses; and as the owner, Monroe Miller, takes not only pride, but 
interest, in the dumb animals he owns, I take pleasure in recording the fact. His stable proper is $160 \times 50$, and every stall has its window over the horse's head, with a miniature awning, to lower when the sun reaches that side. The ventilation is perfect; and the drainage is all that could be desired; and what is the result? When the epizootic was playing havoc with horseflesh in Texas, Mr. Miller did not lose a horse; but, instead, it was the talk of the little city. Cleanliness, light and ventilation saved him, while in other stables king Death was snatching them away in a fearful hurry. To keep a noble and useful horse in a dark stable and theu let him out in a hot summer sun, with the glare suddenly striking the eyes, is -what? Well, I would not like to say.

No stable, nor any part of one, should be under ground; and it should have sufficient drainage, with a fall to every drain of an inch to every yard, to carry off the liquid filth of every stall.

When this is looked at in its right light, the farmer or breeder can see at a glance how he can save money by looking after the comfort of his animals. A few hundred dollars expended in this way would save thousands in time; for when stock is taken sick, the surgeon is called in, medicine is procured, the services of the sick horse is lost, and, take it all in all, at the end of a few years it would cost the farmer or breeder more money in trying to keep his horses well than it would to build a proper stable, and keep his animals in good health. Cobble stones, or red brick laid edgewise, makes the best flooring for a stable. A good sized frame building, loosely weather-boarded externally, lined at the distance of one foot with grooved and tongued inch boards, and having the intervening space filled with tan bark, will make a first-class country stable, because it will be cool in summer and warm in winter.

"Cleanliness is next to godliness," the old saw says; and because some horses, after a hard day's work in the field, or on the farm, are turned out to seek a resting place in the pasture, is no reason why they should not be kept clean. Cleanliness adds to health, 
and they, one and all, ought to be thoroughly cleaned daily, no matter whether they are turned out or in.

Rubbing with the currycomb or brush circulates the blood, and makes healthy perspiration; and no horse will carry a fine coat without it. The farmer will see the necessity of having his horse washed and curried every morning before breakfast, when I tell him that it will increase the spirits of the animal, and in fitting him for his day's labor ; and when he is brought home at night, wet through, covered with mud, and generally filthy after a hard day's work, in bad weather; the man who does not see that horse cleaned off, and made comfortable, is not fit to belong to the Society for the Prevention of Cruelty to Animals. If a horse is freely fed when in that state, inflammation of the lungs or bowels, and colic will certainly follow; and if he is not cleaned, the "scratches" are the natural consequence.

The temperature of a stable should not be above 65 degrees, and the air should be very dry ; for any kind of 'noisture in the stable will hang around the horses like a mist; and when the animals are brought into the air, they will shiver just as if they had a chill.

Whenever the weather permits, the horse should be dressed in the open air, for it braces him up to a degree that is astonishing ; and I have never yet seen the necessity of the attendant using the currycomb as if he was trying to tear the poor animal's skin all to pieces. Such cruelty ought to be prevented, and such stablemen ought never to be allowed to take a comb in their hands; but, instead, give them a hair cloth, with which they can be as rough as they please, and it won't hurt the horse half as bad. In dressing the horse, the head should be first attended to, and the hair should be lifted gently, and combed lightly; the ears should be pulled gently with the hand, and then the whole head should be washed carefully and tenderly; for there is no animal siving, except the $\mathrm{dog}$, that appreciates kindness more than the horse. After the balance of his body is gone over in like manner, he should be wiped 
with clean straw till he becomes glossy ; and then, when his clothes are put on, the legs can be cleaned in the same way. When the horse is brought in wet and exhausted, and signs of inflammation show, steep a flannel bandage in cold water, wring it out, and fasten loosely to the legs. Then cover with a linen bandage, drawn tight, and all signs of inflammation will pass away.

This is about all that can be said in favor of the horse's health; by attending to his comfort and wants, and by following the advice given, the farmer, or owner, will be repaid; yea ! a hundred fold.

\section{CHAPTER THIRTEENTH.}

\section{THE PROPER WAY TO BREAK A HORSE.}

In the United States there is not one horse in fifty that is properly broken, because the stock raiser takes no pains in educating him, being merely satisfied if the horse will pull a load, or take

- kindly to a saddle being placed on his back, expecting all the time that some buyer will come along and take him off his hands. Now, this is all wrong, for a-horse is like a human being in this respect; for when a colt, he is like a child, and will learn anything you tell him, providing the master does it all in kindness. "As the twig is bent, so grows the tree," and this can be said with truth about the horse; for when young, he is flexible, and ready to follow where a good master leads ; naturally good natured and willing, until made vicious by the tricks of bad boys; and there is many a bad horse to-day who would eat his own master up if he had a good chance, that would have been kind of temper and docile as a lamb, had it not been for the aforesaid boys. Now this ought never to be allowed; boys should be punished for punishing the horse. 
A horse to be properly broken, must be under the complete control of his rider, or driver. He must be taught to carry his whole anatomy in the easiest manner possible, and, at the same time, be graceful in carriage. His neck must be like whalebone, yielding to hand pressure, and returning the head to its natural place the moment the hand is taken off. He inust not have what is called hardness of the mouth ; but if he should resist, the pressure of the bit, it must be from high spirits and courage, and his mouth feel to the touch like satin.

He must change his step at the bid of his driver, and must obey every word and touch of his owner

How is this to be done? He should be handled by different persons, and be made acquainted with everything connected with harness, and then he will not be likely to run away, when any of the gear or trappings give way.

While suckling, they should be coaxed and petted; •eating an apple or carrot from the hands, and taught so, that they would be afraid of nothing. A headstall having a ring attached, to which a halter can be made fast, ought to be thrown over them, and then they would learn to follow the person leading them in any pace desired.

Shortly after this, there may be strapped on their back a blanket for a short time daily; and after, have stirrups and straps, which ought to be allowed to swing about loose, and then he will be proof

$=$ against fear, when the proper time comes to saddle him in earnest. When he is a year old, the bit should be put in his mouth once or twice a day ; and he should be allowed to play with it.

After this, the colt should be worked in a circle, in a grass field, having attached to the bit a cord long enough to give him plenty of swing, and in this way the trainer can make him do his bidding; stopping short when called on, or starting off on a gallop; but the operator must be a man of patience, and, above all, good nature ; and if such is the cuse, the balance is only a matter of time. 
A great many people put their horses to work too young, and thereby kili all the life and spirit in them; whereas, if they would not task the colt with any work that was not actually demanded in exercise, before he is five years old, they will add from eight to ten years to his lease of life, and really get more work out of him.

Following this advice will end all the trouble in breaking a colt; and as for putting him in harness, all that is necessary, is to hitch him up alongside of an old horse, on a light farm wagon, handle him easy, speak to him in kindness, and he will soon know what you want him to do.

A wild colt who has had a picnic during his early years, should be kept in the stable for a week, and by degrees made acquainted with harness, wearing it for an hour or two each day. If it is not in the power of the trainer to harness him alongside of a gentle horse, then he should be shown the wagon, and allowed to smell it until it became familiar to him, and then he can be hitched up alone without any danger ; lead him kindly, speak to him gently, and assist him by getting hold of the shaft and pulling it along, so as the weight of the wagon will not come on him of a sudden, and he will become gradually used to it, and in the end rather like it. This is the proper way to train a horse, and unless the colt is very vicious from ill treatment, this mode will prove a certainty.

The wagon and harness should be very strong, so as there would be no chance of breaking; for an accident like that might work serious injury to the horse in after times, because he never forgets anything that frightens him. Do not whip him if possible, try the gentler method; but if you do whip him, don't let him think you are playing with him. If the horse is trained to the saddle first, so much the better; but, if that cannot be done, the above instructions, if carried out, will compensate the person following them. 
THE PROPER WAY TO WORK A HORSE.

There never was a greater mistake made than to say, that a man who owns a horse, and drives a horse, knows all about a horse; for in a majority of cases, it is the very reverse. There are two classes of horses: work and pleasure; and all horses who do puiling and hauling heavy loads, are termed work horses, and the balance are horses of pleasure. It need only be said of working horses, that they should be well cleaned and fed, have their regular hours of rest, and plenty of time before their work commences, to digest their food. It is a mistake to say, that horses, having a long journey to go, are benefited by being driven slowly ; for if the road be good, the weather not too warm, and the load not very heavy, it will be better to drive him at the rate of eight miles an hour than at five miles an hour; for then he will get to his stable sooner, be fed earlier, and have a longer rest for the trials of to-morrow.

Of course, the work of farm horses is generally slow, and they do not need the same attention as fast working horses, and can be fed and watered at almost any time; but with horses of pleasure, everything is different; for as a rule, they are in the stable threefourths of the time, and should never be taken out or driven on full stomachs; which there is never any necessity for ; for if the stable man is apprized of their going out, he can fix the feeding. time to suit the convenience of the horses. When harnessed, and the driver seated, he should never send them off with a jerk, or strike them with a whip; but by speaking to them kindly, allow them to increase their speed by degrees; but never force it.

A steady pace, say ten miles an hour, is more preferable than sending them along by fits and starts. The less punishment a horse gets, the better for all parties; although it is true, that a lazy horse along with a free one, must be kept up to his work; or else the latter will be "played out" before half the trip is ended; and in this case, the whip must be used; but do it gently, so as to re- 
mind him of his duty, but do not hurt him ; and in no case should the whip be given to a horse that is exhausted, for no good is gained by it; while the result may be bad. Fear of the whip causes sudden starting and stumbling, and as the whip cannot cure it, do not use it; but get somebody to hold the horse's head, and when you are ready, let the man lead him along easily, and in this way he will get broke off it, after a while.

A good driver, going at the rate of ten miles an hour, will not drive up hill and down bill at the same rate, but will guide himself according to the road; and ease them up in rough places. If traveling fast, horses should have a sip of water every hour; and if going a long distance, one feed in the centre of the journey will be sufficient. As said before, kindness goes a long way with a horse. This is the best point I can give you, and do not forget it. 


\section{CHAPTER FOURTEENTH.}

SIMPLE DISEASES CURED BY SIMPLE METHODS.

Too much medicine given a horse, acts upon him the same as it does in man; for the more he gets, the more he requires; and, in fact, instead of relieving his complaint, it only adds to it. I know this by experience; for once upon a time, I imagined that I had all the ills that flesh is heir to, and the more I doctored, the worse I got; until I happened to fall in the hands of Doctor Longrigg, of this city, who, in his own blunt manner, told me up and down that medicine, as a rule, was a grand humbug, and the less a man took, the better he would be off. Acting on his advice, I abstained from drugs of all kinds; and from that time to this I have continued to improve in health, and am now as healthy as any man ought to be. I refer to this, believing that man and horse are constructed alike, and the less medicine either get, the better for both.

But there are times when simple purgatives will clean out the system, and be a benefit to any animal; and, in my opinion, the simplest is the best; .so I prefer the Homœpathic system; but as many believe in the other kind of treatment, I will try to give the easiest and best remedies for all diseases contained in both systems.

In any case, never allow a stable attendant to dose a horse unless the owner is present; for there are more quacks centered in and around stables, who have special cures of their own for all diseases; and of all their cures there is not one that is reliable.

The best way to do in all cases is, to call in the best medical authority and leave the horse in his hands; and if he has any repu- 
tation to lose, you can bet that he will do his utmost to cure that horse. There is nothing wonderfully secret in the diseases of the horse; and any man of book sense, and common intelligence, can manage the case himself, providing he is not in striking distance of a veterinary surgeon.

A man may lose a pint of blood and not miss it; but take five quarts from a horse and you can study the result. We believe in mashes, no matter what the complaint is ; and purgation caused by drugs, we detest.

In colic, inflammation of the bowels and lungs, relief must be instant; but as colic and inflammation of the bowels are almost similar, when first appearing, great caution should be exercised by the owner.

Youatt presents the two complaints in tabular form, as follows :

Colic.

Sudden in its attack, and without any warning. Pulse rarely quickened, in the early period of the disease and during the intervals of ease; but evidently fuller.

Legs and ears of natural temperature.

Relief obtained from rubbing the belly.

Relief obtained from motion.

Intervals of rest and ease.

Strength scarcely affected.
Inflammation of the Bowels.

Gradual in its approach, with indications of fever. Pulse much quickened, but small, and often scarcely to be felt.

Legs and ears cold.

Belly exceedingly painful, and tender to the touch.

Pain evidently increased by motion.

Constant pain.

Great and evident weakness.

The remission of pain in the one and the increase in the other, will show, to the practiced hand and eye, the difference in each. Weakness never comes in colic, but shows rapidly in inflammation. The pulse of the horse is felt at the lower jaw, near the junction of the neck and head; place the thumbs on the cheek, outside, with the nail turned unwards, and pass the tips of the fingers 
under and inside the jawbone, feeling the artery, and ascertaining the beating of the pulse, and counting the number given in a minute.

Thirty-five in a minute is the average in temperate climates; and in Texas it ranges ten degrees higher; but very often excitement causes a sudden quickening of the pulse, and the attendant should be as tender and fond as possible, so as to avoid any unnecessary alarm. Giving green corn or cold water, when the horse, is heated, will produce both colic and inflammation. If the horse has colic, give at once, in liquid, held in a bottle, an ounce of laudanum and three ounces of spirits of turpentine, in a pint of warm ale; and in an instant the cure will be perfect. An injection of warm water, in which is dissolved an ounce of Barbadoes aloes, will put a stop to spasms. Rub the belly well with a hot flannel cloth and walk the horse gently afterwards, and the trouble will be over in a few moments. As the horse's blankets will be covered with perspiration, he should be put in a roomy box and fed on bran mashes for a few days, and made to drink warm water, and nothing else.

Bleeding is the best thing for-inflammation of the bowels; for after taking ten quarts from him, the swelling will subside. Give him all the warm water and thin gruel he will take, with two drachms of aloes dissolved in the water.

Tincture of cantharides is an excellent blister, well rubbed in on his belly. The horse should be kept warm, with his legs bandaged, and the blood will begin to circulate; but above all things, give him no grain, nothing but mashes; and after he recovers, a handful of oats, three times a day, will do no harm. Fever and cold limbs always comes before inflammation of the lungs, and he will never lie down, day or night, and appears languid and careless about moving about; and he will stand until he drops dead. In this case the horse must be bled, until he gets tired of standing; and part of the blood should be held in a glass which, when cold, will show a thick buff colcr. Blister him with a pre- 
paration made out of four parts of lard, one of rosin, and one of cantharides, and rub strong and bard. Melt the lard and rosin together and add the flies. Purging is not necessary in this case; but a dose of nitre and tartar emetic given morning and evening will be of great benefit to the horse. Keep him in a cool box with legs well bandaged, warmly blanketed, and rub his skin without irritating him. The great desideratum, mashes, should be given I im ; but no grain.

This disease generally ends in broken wind, and the sooner he is got rid of, the better for his owner; but all simple diseases such as a cough, constipation, worms, distemper, strangles, etc., should be cured by the owner himself, with common medicines, which can be had of any druggist; and buy the same medicine you would use yourself, if having any of those complaints. As I have said many a time before, cleanliness and proper food knocks the life out of all disease; and if the farmer or breeder adheres to the first principles of health, there will be little need of medicine.

Bleeding is generally done in the jugular vein, with a broad bladed lancet; and when the vein is sufficiently pressed and secured, so as to cause it to swell; then the point of the lancet is sent in with the left hand, and cutting upwards, makes all the opening necessary. When sufficient blood is taken, the cut ought to be squeezed together and fastened with a pin. By pressing the vein below the wound, the blood will shoot out in a stream and fall clear into the bucket ready to receive it; and it would be a good thing if the same pail was used every time; as the amateur surgeon would be more likely to know how much it would hold.

Medicine if given in balls should never be more than an ounce and a half in weight. Take the ball in the right hand, and with the bare arm, run into the mouth as far as possible, drop the ball with a jerk, and then it is forced down the throat; but if it should get fast, touch the chin in a playful mood, and away it goes.

Purgatives I do not believe in, as a general rule; but as desperate $3 *$ 
cases require desperate remedies, I will say that aloes, fresh, are the safest I know of. Five drachms is a dose at any time, and if the horse should be fed for a few days on my favorite mashes, a small dose of aloes will do as much good as a large one; if the horse has not had his mashes, avoid castor, olive, and linseed oils, as you would a plague; for although some smart jockeys still use those horrid dangerous drugs, they are no good, and very likely will do harm.

The best remedy for constipation I have ever seen used, was the private inventiou of my fricnd Sam Richards, in Austin, Texas; and what those people don't know of a horse, is not worth knowing; it was merely an injection of suds, made out of Castile soap, having a little Croton oil mixed with it. Mashes, warmth and cleanliness will cure a sudden or common cough, but darn the medicine; let it alone.

Distemper is a common complaint in a colt or filly, but, like the measles in children, once they pass through it, there is nothing more to fear. If the poo: horse should be changed into a dog, at this period of his life, the majority of wise people would say that he was mad, because he refused water, and had a flow of saliva from the mouth, and a common discharge from the mouth; but neither the dog or horse is mad in this stage. Blister, poultice and steam, and the end will not be far off : but always remember, cleanliness and proper food.

Botts and worms give some people a great deal of uneasiness; but both are harmless while in the stomach. Any common surge will bring the white worm out of his hiding place. Aloes and warm water, in shape of injections, are the best remedy for those little pests.

Nitre will relieve the bladder from all imperfections, and force an easy flow of water.

The scratches are caused by neglect in drying a horse's feet and heels, when wet after a hard day's muddy work. If not taken care 
of, the hair drops off, the skin becomes glazed, and the heels swell; the legs, nearly to the hock, are full of hard, thick scabs, from which matter runs that is very offensive. When this disease first appears, the free use of Castile soap and luke-warm water will work wonders; and a bandage of flannel, wet in warm water, and allowed to dry on the part affected, will work well. Mix one ounce of lard with a drachm of sugar of lead, and anoint the sores; while three ounces of alum, dissolved in water, and used as a wash, wherever the cracks appear. All high food should be kept away from him, and after a couple of days' diet ou bran mashes, five drachms of aloes given in a ball will effect a cure; but when the disease is allowed to cure itself, which it never does, carrot poultices must be put on very hot; and, when taken away, an equal mixture of rosin and lard, melted together, to which add one part of calamus, and use as an ointment. Whenever there is fever, poultices made out of carrots will be found very beneficial.

Another simple ailment is known as the thrush, which is a discharge of nasty matter from the frog of the foot. Get an ounce of white vitriol, two ounces of blue vitriol, which must be powdered very fine, and rubbed into two pounds of lard and one pound of tar. Cover a bundle of tow with this preparation, and, without any force, put it in the frog as far as you can, and remove it every morning. Keep the feet moist with cow dung, tar and soft clay.

When a horse falls lame, after shoeing, examine the foot and see if the hoof has not been pricked by the driving of nails into the flesh. If so, inflammation will follow, and the shoe must be taken off, the nail removed, and the hole made must be opened out by paring; when a bundle of tow, saturated with Friar's Balsam, should be driven into the hole or sore.

\section{BROKEN KNEES.}

Where a knee has been broken by a fall, the wound should be washed carefully with luke-warm water, and all sand, gravel 
or dirt must be instantly removed; and if there is much swelling, do not poultice, butferment it. Keep everything stimulating, astringent or warm, in the way of poultices, away, and in a short time the horse will begin to improve. When one foot is injured by the caulks of the other, the above treatment will have the same effect. Strains, contusions, or wrenches, ought to be bandaged with flannel, steeped in hot vinegar and water, and repeated constant will ensure a cure; but when there is much swelling, poultices of carrots, linseed or turnips, should be bandaged tightly; and when the inflammation passes away, and lameness and weakness continue, that part ought to be bandaged nightly with a cotton cloth, steeped in cold water, and tightly wrapped in a double flannel above that part. This will effect a permanent cure nine times out of ten.

All simple complaints can be attended to and cured by any person if the above advice is followed, and the ingredients mentioned can be found in every house ; but for all serious accidents or maladies, it would be nonsense to attempt to cure from simple recipes, and in such cases the best medical treatment is compulsory. 


\section{CHAPTER FIFTEENTH.}

HOMOPATHY FOR THE HORSE.

Hahnemann says: "In order to cure a disease, select such a remedy as is capable of producing a similar malady in a healthy person, and of such a remedy prescribe only a small dose."

Now, whether this is so or not, I will not pretend to say; but this much I do know, and that is, that I would not like to be the healthy person experimented on; but believing that the simplest remedies are the best when compelled to resort to medicine, which I disapprove as a rule, I then pin my faith to homœopathy, believing that of the two systems this is the best.

The medicines used in this treatment are generally in liquid form, and the greatest care should be taken in the mixing. The ingredients can be purchased at any drug store, and are so cheap, that the farmer ought to keep a full assortment in a medicine chest; and as each article will last for years, I think this would be a good policy.

Another reason why I like this system of doctoring is, that the name of each particular medicine is familiar to everybody, and if they do no good, they can do no possible harm, being nothing but herbs, barks, and vegetable matter that we often have heard our grandmother speak of in good old English. What harm can there be in the following, if used with discretion: 

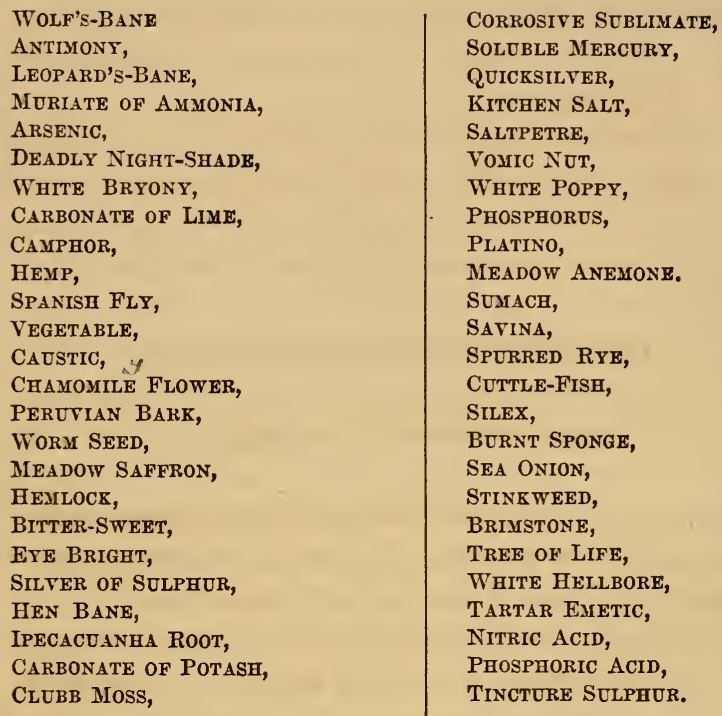

There they are, and where is the one that every country boy is not acquainted with? As they are put up in liquid shape, take a piece of bread, and put six drops of the medicine on it; then raise the horse's head, press down the tongue, and pull it out as far as possible, and then place the dose as far back as you can; close the mouth with the hand, and with a gentle tip under the chin, the horse will be compelled to swallow the piece of bread.

When the first dose acts favorably, and then a relapse should take place, give a second dose of the same medicine. In all rapid diseases, such as pneumonia, glanders and pleura, the medicine should be given every five, ten or fifteen minutes. In serious diseases, an improvement is always shown after the first dose, and that is the time to repeat it, when the second dose will, in all likelihood, perfect a cure. When the disease becomes chronic for the time of four days, the medicine should be given as described; but if there are any signs of the complaint becoming better, then stop 
giving medicine for awhile; repeat the medicine if the improvement stops; and if there should be no improvement in a few days, change the medicine.

For burns, bruises and all other injuries, take arnica, symphytum and urtica urens, from twenty to thirty drops in half a pint of water, and according to directions given use it. In this treatment, as in everythiug else, a proper diet, and attention to cleanliness will have great weight in assisting the medicine to make a cure. Everything that interferes with the regular mode of physicing, must be disregarded; but simple injections of salt water and soap will do no harm. Half an hour should intervene between the medicine and food.

In the treatment of sick animals, Rush says : As soon as an anima! becomes sick, let it be immediately placed in a house by itself. This is necessary, both for the welfare of the sick animal and for the safety of others. The house that the animal is placed in ought to be warm, well lighted and ventilated, and, above all, kept scrupulously clean. Let the person who attends to the wants of the animal, be very cautious to approach in a quiet manner, never making any unnecessary noise, or do anything to irritate the animal, when in a state of health.

In rapid diseases, no food should be given, until there is a change for the best, and then in light feeds.

Bran may be given either dry or wetted, whichever way the animal prefers it.

Oats may be given mixed with the bran, either raw or crushed, or whole or boiled.

It is necessary to keep the animal without food or water for half an hour before and after administering the medicine.

In acute diseases, it is necessary to repeat the dose every five, ten, fifteen or twenty minutes.

In less acute diseases, every two, four, six or eight hours.

In chronic diseases, once in twenty-four hours is sufficient. 


\section{REMEDIES FOR SPECIAL DISEASES.}

\section{Mange.}

The principal medicine to be used in this disease is Sulphur, of which six drops must be given every day for three weeks ; afterwards, the following medicines will be found useful: Arsenic, Cuttle-Fish and Sumach. If the hair falls off, and the skin becomes loose and flabby, or if there are any ulcers with hard red edges, use Arsenic.

Dose-Six drops night and morning.

Cuttle-Fish, if the parts affected are tender, and the animal shrinks when touched, or if there are white looking blisters filled with a watery fluid.

Dose-Six drops night and morning.

Sumach, if there are hard, elevated patches or scabs that do not fall off of themselves, and, if taken off, others soon form in their places.

Dose-Six drops, three times a day, until better.

\section{Farcy.}

Remedies.-Wolf's-Bane, Arsenic, Peruvian Bark, Sumach and Tree of Life.

Wolf's-Bane, if accompanied with fever, in which case the swelling is hot and painful, the animal refuses to eat, is restless, and moves about from place to place.

Dose-Six drops or twelve globules, three or four times a day.

Arsenic and Peruvian Bark alternately, if the swelling is cold. Dose-The same as prescribed for wolf's-bane.

Sumach, if with hot swelling there is great stiffness of limbs.

Dose-Six drops or eight globules, morning, noon and night.

Tree of Life, if there are any pimples or hard patches, or if the animal frequently stretches his limbs, and a crackling is heard at the same time.

Dose-The same as the last. 


\section{Scratches.}

Remedies.-Tree of Life, Spurred Rye, Arsenic, Quicksilver and Sulphur.

Tree of Life, both internally and externally, if they are bluish and brownish excrescences, which bleed on the least touch, and there is a discharge of fetid matter.

Dose-Six drops three times a day; at the same time the parts may be bathed with the strong tincture night and morning.

Spurred Rye and Arsenic may be used in alternation, if there is a watery swelling or dark looking ulcers, with fetid discharge.

Dose-The same as directed in the last; internally.

Quicksilver, when there are numerous small ulcers that discharge a thick matter, and bleed when touched.

Dose-Six or eight drops twice a day.

It is necessary to give a dose of Sulphur once a week during the treatment, and keep the legs clean by washing them with warm water.

\section{Foundex.}

Revedies. - Wolf's-Bane, White Bryony, White Hellbore, Arsenic and Sumach.

Wolf's-Bane, if there is inflammation; the animal stands as if rooted to the spot, the breathing is hurried and interrupted, the breath is hot, and the pulse accelerated.

Dose-Six drops every one, two and three hours.

White Bryony, complete stiffness of the limbs, with swelling of the joints.

Dose-Six drops every two hours.

White Hellbore, if it is brought on by violent exercise.

Dose-The same as wolf's-bane.

Arsenic, if it is caused by bad or heating food, or after a cold drink when overheated.

Dose-Six drops every one, two and three hours. 
Sumach, if there is much pain in the feet, and the animal is very stiff in his movements.

Dose-Six drops or eight globules three times a day; at the same time the limbs may be bathed with a solution of Sumach, externally, twice a day.

\section{Hide Bound.}

Revedies.-Arsenic, Antimony, Quickilver and Sulphur.

Arsenic, if there are hard scurvy patches about the skin, coldness of the skin, general emaciation and loss of strength.

Dose-Six drops three times a day until better.

Antimony, if there are rough scales on the skin, coat very rough, loss of appetite, and excessive thirst.

Dose-Six drops in a little water night and morning.

Quicksilver, if the animal has fits of shivering; the hair falls off from various parts and leaves the skin of a dull leaden color; voracious appetite, or unnatural appetite; eating of dirty litter and even dung.

Dose-Six drops night and morning.

Sulphur, as an intermediate remedy, may be given twice a week during the whole treatment.

Dose-Six drops in a little water.

\section{Thrush.}

Remedies. - Tincture of Sulphur, Phosphoric Acid, Sea Onion and Arsenic.

Tincture of Sulphur is considered most specific for this disease. Dose-Six drops night and morning, until cured.

Phosphoric Acid is used in the same way, providing the former does not reach the disease.

Sea Onion, if there is fever or inflammation of the parts.

Dose-Six drops night and morning. 
Arsenic, if the discharge is very fetid, and there is lameness, the foot very hot and painful.

Dose-Six drops three times a day.

\section{Megrims.}

Remedies. - Wolf's-Bane, Deadly Night-Shade, Arnica, Opium and Sulphur.

Wolf's-Bane will be serviceable, and may always be given, especially if during an attack the horse falls down, and in trying to get up, falls.

Dose-Four drops every hour until delivered, after which it may be repeated at longer intervals, increasing them until the horse is cured.

Night-Shade, if the animal turns quickly around, falls down and continues to struggle and lie quietly.

Dose-The same as before.

Arnica, if the disease is supposed to arise from mechanical injury.

Dose-Six drops every hour.

Opium, if the animal lies stupid as if dead.

Dose-The same as the last.

\section{Inflammation of the Brain.}

Remedies. - Wolf's-Bane, Deadly Night-Shade, White Hellbore and Opium.

Wolf's-Bane, in the very commencement of the disease, if the pulse is accelerated, fever, congestion towards the brain, rapid breathing, and trembling of the whole body.

Dose-Six drops every twenty minutes until several doses have been taken, or the violent symptoms have passed away, after which the following remedy should be thought of : 
Belladonna, if the animal has a wild look and dashes about furiously, which indicates violent congestion of the brain.

Dose-Six drops put on the tongue every thirty minutes, until the violence is subdued.

White Hellbore, if the legs and ears are very cold, with trembling of the whole body; or where there is a staggering motion, and the horse plunges, falling head foremost.

Dose-The same as the last.

Opium if, after the fit, the horse stands perfectly quiet, with eyes fixed on vacancy, and the tongue black or leaden in color.

Dose-Six drops every half hour, according to his condition.

\section{- Catareh.}

Remedies.-Wolf's-Bane, Nux Vomica, Bitter-Sweet, Sumach, White Bryony, Arsenic, Quicksiiver and Meadow Anemone.

Wolf's-Bane will be useful in the beginning of the disease if there is fever and heat of the body, restlessness, short breathing, red urine, thirst violent, and the nostrils stopped up.

Dose-Six drops every three hours, until better.

Nux Vomica, if the tongue be coated white, with the mouth dry, a nasty odor coming from the mouth, and a bloody or watery discharge from the nose.

Dose-Six drops twice a day.

Bitter-Sweet, if the attack is brought on from exposure, and the horse is drowsy.

Dose-Six drops twice a day.

Sumach, if the cough is short and the nostrils stuffed up.

Dose-Four drops three times a day.

White Bryony, if the breathing is difficult, the cough dry, and the nose swelled.

Dose-Four drops three times a day. 
Arsenic, if the discharge continues too long, the nostrils become corroded.

Dose-Six drops twice a day.

Quicksilver is good in the first stage of the disease.

Dose-Six drops three times a day.

Meadow Anemone, if the discharge is green and the cough loose.

Dose-Six drops three times a day.

\section{Cough.}

Remedies.-Bitter-Sweet, Nux Vomica, Sea Onions, White Bryony, Muriate of Ammonia, Meadow Anemone and Clubb Moss.

Bitter-Sweet, if the cold comes from exposure, and there is a slight discharge from the nose.

Dose-Five drops three times a day.

Nux Vomica, if it be a dry cough, and when leaving the stable it commences.

Dose-Five drops three times a day.

Sea Onions, if the whole body shakes, and the horse groans before coughing.

Dose-Four drops twice a day.

White Bryony, if the cough has lasted for any length of time.

Dose-Six drops night and morning.

Muriate of Ammonia, if the horse is losing flesh, and about to choke or vomit.

Dose-Four drops every three hours.

Meadow Anemone, if from the cough there comes a bad smell, or the horse becomes easily frightened.

Dose-Four drops every three hours.

Clubb Moss, if drinking incites the cough, and makes it come on in fits.

Dose-Six drops three times a day. 
During this sickness, raw or boiled carrots are the best food to give the horse, with plenty of oats and mashes thrown in.

\section{Sore Throat.}

Remedies.-Wolf's-Bane, Quicksilver, Belladonna, Burnt Sponge, Clubb Moss and Sulphur.

Wolf's-Bane, if the fever is attended by dry heat, and the parts touched are red and swelled, with great thirst and swallowing not easy.

Dose-Four drops every two hours.

Quicksilver, if the glands of the neck are swelled, and much frothing of the mouth.

Dose-Six drops three times a day.

Belladonna, if the breathing is difficult and the throat shrinks, with difficulty of swallowing.

Dose-Six drops three times a day.

Burnt Sponge, if the breathing is accompanied with a rattling sound, and the horse, in turning his head, appears to be suffocating.

Dose-Six drops every two hours.

Sulphur, in contrary cases, with painful swelling.

Dose-Six drops night and morning.

Clubb Moss, if the mouth smells badly, with sweating and swelling of the under jaw.

Dose-Six drops morning and night.

\section{Inflammation ofthe Lungs.}

Remedies.-Wolf's-Bane,Phosphorus, White Bryony, Belladonna, Tartar Emetic, Liver of Sulphur, Quicksilver, Ipecacuanha, Sumach, Sea Onion and Sulphur.

Wolf's-Bane, if there is much fever and a quick pulse, dry skin and thirst, this remedy is considered the best if used immediately.

Dose-Four drops every twenty minutes for three hours, and then lessen the dose. 
Phosphorous may be used after wolf's-bane has eased the pain. Dose-Four drops every two hours until the violence ceases.

White Bryony can be used if the breathing be difficult.

Dose-The same as the last.

Belladonna, if the cough is dry, and the breathing difficult.

Dose-The same as the last.

Tartar Emetic, if the cough comes on irregular, and the pulse can hardly be felt.

Dose-Four drops every three hours.

Liver Sulphur, if abscesses are formed, and the breathing is deep.

Dose-Six drops three times a day.

Quicksilver, if the cough is dry, and the discharge great, smothered breathing, and sweating.

Dose-Six drops three times a day.

Ipecacuanha, anxious breathing, red eyes, and a noisy throat.

Dose-Six drops every two hours.

Sumach, if the chest is oppressed when breathing, the nose red and painful to the touch, and a spreading of the legs.

Dose-Six drops every two hours.

Sea Onion, violent cough, and a longing wish to urinate.

Dose-Four drops every two hours.

Sulphur, getting relief by spitting, with discharge of lumpy, green matter.

Dose-Six drops three times a day. For the first few days no food must be given, except cold bran mashes, carrots, and a little hay; but if everything goes on right, a dose of oats can be given. Cleanliness and plenty of cold water will work the rest.

\section{Infuenza.}

Remedies.-Wolf's-Bane, Quicksilver, Belladonna, Arsenic, and White Bryony. 
Wolf's-Bane is always used in the commencement, and if swelling, sneezing, or dry cough is shown, and running pool from the nostrils.

Dose-Four drops every three hours.

Quicksilver, if the eyes water, the light is offensive and the throat is filled with matter.

Dose-Six drops three times a day.

Belladonna, when the eyes are inflamed, fluids are hard to swallow, and the head is affected.

Dose-Four drops every three hours.

Arsenic, if the body be heated, evacuation, bloody and loose, and a general weakness.

Dose-Four drops three times a day.

White Bryony is very useful, and may be substituted for wolf's-bane, if the latter has no effect.

\section{Gripes.}

Remedies. - Wolf's-Bane, Arsenic, Nux Vomica, Opium, Chamomile Flower, Meadow Saffron and Henbane.

Wolf's-Bane, if the pulse is fast and the mouth dry.

Dose-Four drops every fifteen minutes; and if the third dose does not bring relief, take up the next remedy.

Arsenic, if indigestion or bad food is the cause.

Dose-Six drops every hour.

Nux Vomica is only useful when constipation is the cause.

Dose-Six drops every hour.

Opium, when nux vomica fails, opium will be a success.

Dose-Four drops every two hours.

Chamomile Flowers, when the horse is restless, and the bowels are relaxed, and an evacuation soon follows an attack of pain.

Dose-Six drops every hour, until the case improves. 
Meadow Saffron, if green food is the cause, and the horse strikes at his belly with his hind feet.

Dose-Six drops every hour.

\section{Indigestion.}

Remedies.-Antimony, Ipecacuanha, Nux Vomica, Arsenic, Peruvian Bark, Silex and Sulphur.

Antimony, if the appetite is lost, and there is a craving for drink, with offensive discharges.

Dose-Six drops night and morning.

Ipecacuanha, if the passage is green, and the food is vomited.

Dose-Six drops night and morning.

Nux Vomica, in case of constipation, this remedy is very good.

Dose-Six drops night and morning.

Arsenic, if diarrhœa comes with bloody discharges.

Dose-Six drops twice a clay.

Peruvian Bark is good for a young horse, especially if the complaint is caused by overwork.

Dose-Four drops three times a day.

Silex will ease the perspiration.

Dose-Four drops three times a day.

Sulphur can be given in any stage of the disease.

\section{Diarrhoea.}

Remedies.-White Bryony, Arsenic, Sulphur, Chamomile Flowers, Meadow Anemone, Bitter-Sweet and Peruvian Bark.

White Bryony is good when the complaint is brought on from sudden heat or cold.

Dose-Six drops every three hours.

Arsenic, if without pain, and caused by green food.

Dose-Six drops every two hours. 
Sulphur can be given with Arsenic, when the passages are offensive.

Dose-The same as the last.

Chamomile Flowers are good when the horse is restless, and the belly commences swelling.

Dose--The same as the last.

Meadow Anemone, if there is a disgust for food, and the stools are frequent, with wind plenty.

Dose-Six drops three times a day.

Bitter-Sweet is good when colic accompanies the disease.

Dose-Six drops three times a day.

Peruvian Bark, when the complaint becomes intermittent.

Dose-Six drops three times a day.

\section{Inflammation of the Bowels.}

Remedies. - Wolf's-Bane, Sumach, Nux Vomica and Arnica.

Wolf's-Bane is the chief dependence in this complaint, and should be given until the pain is eased.

Dose-Six drops every fifteen minutes.

Sumach, if the belly is in a sweat, and the urine comes frequent, with a hot and cold feeling.

Dose-Six drops every two hours.

Nux Vomica, if after the trouble is all over, the bowels are constipated.

Dose-Six drops morning and night.

Arnica, when the passages are nothing but slime, and the urine is retained, there will be found virtue in this remedy.

Dose-Six drops every hour.

\section{Worms.}

ReMediEs. - Wormseed, Sulphur and Soluble Mercury. 
Worm Seed, if the horse is continually rubbing, and there is an itching of the parts, after a discharge of worms.

Dose-Six drops three times a day.

Sulphur, after a hard passage.

Dose-Six drops three times a day.

Soluble Mercury, if, after a discharge of large worms, there is a thumping of the sides, and soreness.

Dose-Six drops twice a day.

\section{Inflammation of the Kidneys.}

ReMedies.-Wolf's-Bane, Arnica, Bitter-Sweet, Hemp and Quicksilver.

Wolf's-Bane is very good, if the urine deposits a thick muddy gathering.

Dose-Six drops three times a day.

Arnica, if an accident is the cause of the trouble this remedy will be found excellent.

Dose-Six drops morning and night.

Bitter-Sweet is very good if exposure is the cause.

Dose-Six drops morning and night.

Hemp, if the horse paws the ground, strains, is restless, and kicks at his belly.

Dose-Six drops four times a day.

Quicksilver, if the horse makes water too fast, and perspires profusely.

Dose-Six drops four times a day.

Remember always, that cleanliness is next to godliness. 


\section{CHAPTER SIXTEENTH.}

\section{WHAT VETERINARY SURGEONS DO.}

There are a great many little odds and ends that the amateur can attend to without any knowledge of the theory of surgical operations, providing he has intelligence enough to be practical. It is true, that a graduate could do all of these things better than an amateur, but there are times when a professional is not within reach, and in such a case, it is well to know all the little secrets connected with the business. Farriers are as thick as snakes, from Maine to Texas, and they all know everything about the horselet them tell it; but if a veterinary surgeon pumps them a little, they get dry very soon, and all their knowledge of the horse vanishes like air. Knowing this, it will do the farmer no hark to know as much, at least, as the farrier, and with that object in view, I commence this chapter.

As I said in a former chapter, I do not beliere in castration; but as it will be done, I will advise the easiest and safest methods for so doing.

Mr. Youatt is the best authority on this subject that we know of, and believing so, we will give his opinion instead of advancing our own. Says Youatt: "The period at which this operation may be best performed, depends much on the form and breed of the colt, and the purpose for which he is destined. For the common farm horse, the age of four or five months will be the most proper time, or, at least, before he is weaned. Few horses are 
lost when cut at that age. Care, however, should be taken that the weather is not ton hot nor the flies too numerous.

If the horse is designed either for the carriage or for heavy draught, the farmer should not think of castrating him until he is at least a twelvemonth old; and, even then, the colt should be carefully examined. The castration should be performed early in the spring, or early in autumn, when the air is temperate, and the weather dry.

No preparation is necessary for the sucking colt, but it may be prudent to bleed and physic one of more advanced age. In the majority of cases, no after treament wiil be necessary, except that the animal should be sheltered from intense heat, and more particularly from wet.

Nicking and docking is another barbarous and unfeeling way of making a horse look well by cutting his tail, depriving him of the power of self protection from insects, and, in fact, depriving him of his real beauty; for what looks nicer than a long flowing tail. Now, it seems to me that in this enlightened nineteenth century, people ought to be intelligent enough to know that if it was not right for a horse to remain entire as he came into the world, God would never have fashioned him so in the first place, and, I think, the person who would abuse or maltreat such a noble animal, has about as much respect for Him as he has for the horse. If a horse's tail be in your way, and it should accidentally touch your face on a wet day," tie it up.

Bleeding a horse when almost in complete health is, I am glad to say, going out of use, for as I have before remarked about medicine, the more he gets the more he needs; and it is so with bleeding, for I have noticed that those who believed in this remedy for all ills, finally had to keep it up to save the horse's life from death by apoplexy; but there are times when, like everything else, it has to be resorted to, and then it should be done by proper hands. 
Youatt describes bleeding thus:

The operation is performed with a fleam, or lancet. The first is the common instrument, and the safest, except in skilful hands. The lancet has a surgical appearance, and is always used by the professional. A piece of hard wood loaded at one end with lead, is used to strike the fleam into the vein, and as this is sometimes done with great violence, the opposite side of the coat of the vein is wounded, often causing a bad case of inflammation. If the fist be doubled and the fleam is sharp and is struck with sufficient force with the lower part of the hand, the stick may be dispensed with.

For general bleeding, the jugular vein is selected. The horse is blindfolded on the side on which he is to be bled, or his head turned well away. The hair is smoothed along the course of the vein with the moistened finger; then with the third and little fingers of the left hand, which hold the fleam, pressure is made on the vein sufficient to bring it fairly into view, but not to swell it too much, for then, presenting a rounded surface, it would be apt to roll or slip under the blow. The point to be selected is about two inches below the union of the two portions of the jugular at the angle of the jaw. A fleam with a large blade is best, for the operation will be shortened, and a quantity of blood drawn speedily will also have far more effect on the system than double the weight slowly taken, while the wound will heal just as rapidly.

In foot cases, blood may be taken from the coronet, or from the toe, by cutting down with a fine knife at the union of the crust and the sole at the very toe, until the blood flows, and, if necessary, encourage its discharge by dipping the foot in warm water. The bleeding may be stopped, by placing a bit of tow in the little groove that has been cut, and tacking the shoe over it.

THE PROPER WAY TO TREAT WOUNDS AND STRAINS.

Incised wounds are those inflicted with a sharp instrument, and if they are seen shortly after, and there be found no dirt, the blood 
had better be allowed to remain, for its healing qualities are well known. Nothing else is needed, except to keep the horse on low diet, if he is to be confined in the stable.

Contused and lacerated wounds may be cured by a charcoal poultice, or an application of myrrh.

Punctured wounds often cause lockjaw and fistula, but a poultice of flaxseed and balsam will give relief.

It has been the custom to cut the hair away from inside the ear, but as that hair protects the ear from cold, it should never be touched except the edges.

Strains are cured by the use of the seton, with blistering and rest combined. A setou is a piece of cord, passed by a needle through the skin, and then held by tying both ends in a knot. The cord is moved in the wound twice a day, and sometimes it is saturated with spirits of turpentine, so as to make the inflammation greater. All other strains are cured in like manner; and an ounce of cream of tartar in one bucket of water, given daily, will have a good effect.

Galling and chafes may be easily cured by sprinkling a little fine powdered flour or table salt over the sore, and letting the horse rest for a day or two. 


\section{CHAPTER SEVENTEENTH.}

\section{THE PROPER WAY TO SHOE A HORSE.}

Proper attention ought to be given to this subject, as more horses have been ruined by bad shoeing than by anything else. In taking the old shoe off, all the clinches of the nails should be raised, without giving the horse any pain, then rasp the outer edge of the crust, but never use that instrument on the surface. The sole should never be paired very thin, for bruises will be the consequence, as the foot is very sensitive, and a loose stone may do incalculable injury. Low heels should always be pared, but never rasped; and bere it may be said, that paring is a work of more labor than a person would imagine, although to stand and look at some blacksmiths, one would think the job easy, for as a rule, they give themselves as little trouble as possible; and the horn which in a foot unshod would be worn away by rubbing against the ground, is suffered to grow, month in and month out, until the sole is destroyed, and it can no longer descend, and then corns and inflammation follow as a matter of course. That portion of the horn which defends the internal part of the foot, and keeps it from getting bruised, ought not to be touched; but the heels should be looked after, for there is a terrible stress thrown on the inner heel, and the horn wears away faster there than anywhere else, and the shoer should be very careful.

For common work, shoes should be pretty heavy, and should be wide, and of equal thickness; so that they will protect the sole. 
The shoe must be made to fit, for no amount of shaving can bring to an unnatural figure, and le.sve the foot safe to work it. A small turn in at the toe will prevent the shoe going backwards, and the shne should be fully long so as to support the heels; and not so short, that a little wear drives the edge of the shoe into the horn. The surface should have a flat place all around it, so as the crust will have ronm to bear up on it f for the crust sustains the whole weight of the horse, and needs to be even everywhere. Great care should be had in opening the nail holes, in giving them a direction outwardly, and allow the points of the nails to come out in the bottom of the crust. The fuller of the shoe ought to go back to the heels, and then it will hold the shoe to the ground.

A shoe should never be burned into place, as the heat might produce something serious; but it can be lightly touched to the font, so as to show where paring is needed most; and then if the shoe is an exact fit, there will be no danger of its getting loose. In nailing the shoe fast, five nails are sufficient in the fore shoes, and seven in the hind shoes; and they should be driven up lightly, and brought out speedily, and then clinched; and the clinches must not be rasped too fine, but turned down firm. The whole surface of the hoof should never be rasped, as the protection given by nature to guard against the moisture of the hoof evaporating too speedily, would become destroyed.

There is no use in being as particular about the hind feet, as about the fore feet, as they are less liable to injury, but not always so; but the shoe should be fitted carefully, and especially at the heels.

Bad shoeing will cause the feet to become contracted; which can only be remedied by forming the shoe so that a level and secure support will be given to the heels. 


\section{CHAPTER EIGHTEENTH.}

RULES OF RACING AND BETTING AS ADOPTED BY THE AMERICAN JOCKEY CLUB.

There are many cities and towns in the United States, where racing would become popular, if the people only knew how to carry the sport, and wishing to give them all the information necessary, we print the following rules of the American Jockey Club, to which association we tender thanks for the favor conferred:

\section{RACING RULES.}

\section{RULE 1.}

AGE.

Race-horses take their ages frum the first of January.

\section{RULE 2.}

MAIDEN HORSES.

A maiden horse or mare is one that has never won a purse or sweepstakes in any country.

\section{RULE 3.}

A PURSE.

For a purse, no person can enter, either in his own name or in that of any other person, more than one horse of which he is wholly or in part owner, unless permitted to do so by a special clause in the conditions.

Horses entered for a purse are not obliged to start. 
Entrance money to a purse shall be five per centum on the amount of the prize, shall be paid at the time of naming, and, when not otherwise distributed by the article, shall go to the second horse.

The article not stipulating otherwise, entries of horses for a purse shall be deposited in a box kept for that purpose, at the Judges' Stand, by four o'clock P. M. of the day previous to the race, unless the races of the day be not finished by three o'clock; and in such case, before thirty minutes after the close of the last race. No entry shall be received after the time specified; and the box shall not be opened except in the presence of an officer or Governor of the Jockey Club.

\section{RULE 4.}

SWEEPSTAKEB.

A sweepstakes is a race, the prize for which is the aggregate of the stakes which the nominators of the horses agree to deposit; and if an additional sum of money, cup, piece of plate, or other reward is offered to the winner, the race is still a sweepstakes, whatever be the name given to such addition. Three subscribers make a sweepstakes; and if a stake has the required number of subscribers at the expiration of the time of closing, and the number is afterwards reduced by drath (or, in the case of a produce stake, by failure of produce), the race is not void so long as there are two horses left, the property of different persons; and if the number is reduced to two, it is still a sweepstakes.

\section{RULE 5.}

POST MATCH OR POST STAKE.

For a post match or post stake, a subscriber is obliged to declare the horse he intends to run at the time for weighing.

\section{RULE 6.}

HANDICAP.

A handicap is a race for which the horses are weighted according to their merits, in the estimation of the handicapper. 


\section{RULE 7.}

ORDER OF STARTING.

The places of horses in starting shall be determined by lot, by the Clerk of the Course. The winner of a heat shall, at the next start, have the inside position; the others shall take their positions on his right, in the order in which they came out in the previous heat.

Nevertheless, the Starter may place vicious or unruly horses where they cannot injure others.

\section{RULE 8.}

OMISSION OF WEIGHT.

When a match or sweepstakes is made, and no weight mentioned, the horses shall carry the established weight for age.

\section{RULE 9.}

OMISSION OF DISTANCE.

When a match or sweepstakes is made, and no distance mentioned, the distance shall be that which is usually run by horses of the same age as those engaged, viz. : if two years old, six furlongs; if three years old, one mile and a half; if four years old, two miles and a half; and if five years old, or upward, three miles; and if the horses be of different ages, the distance shall be fixed by the age of the youngest.

RULE 10.

OMISSION OF DAY.

If the meeting be specified and no day mentioned for a race, it shall be run on any day in that meeting the Executive Committee may appoint; if neither day nor meeting be mentione l, then it shall be run during the meeting in progress, or during the next meeting, should the race be made between meetings-in both cases, on the day the Executive Committee may appoint.

\section{RULE 11.}

OF DRESS AND COLORS.

All riders must be dressed in jockey costume-cap and jacket of silk or satin, breeches of white cords, flannel or buckskin, and 
top-boots. The colors selected by owners are to be recorded with the Clerk of the Course, and, when thus recorded, are not to be used by others, except in case of death or withdrawal from the turf for five ycars. A list of all colors that have been recorded is to be po:ted in the Judges' Stand.

\section{RULE 12.}

\section{NOMINATIONS AND ENTRIES.}

In all nominations and entries, the horse, mare or gelding entered must be clearly identified. The color, sex, name, age, sire and dam must be given, and if the dam has no name, such further pedigree and description must be added as will distinguish the horse intended to be named from any other of a similar pedigree. If the dam was covered by more than one stallion, the names of all of them must be mentioned. When a horse has run once over the Course of any ricognized association, it will be sufficient afterward to give his name and age. If the name of a horse which has run be changed, it is necessary, in naming or entering him, to give his old as well as his new name, until he has run once under it over a course as above; and, if his name be changed again, all his names must be repeated for a like period; but if a horsu's name be changed before he has run in public, it shall be sufficient to give his new name in the first entry made afterward.

\section{RULE 13.}

INSUFFIOIENT DESCRIPTION A DISQUALIFICATION.

If any horse be entered or named without being identified as before directed, he shall not be allowed to start in the race, but his owner shall be liable to pay the forfeit, or, if a play or pay race, the whole stake.

If a horse has been properly described, and from that description is not qualified for the race in which he is engaged, the entry or nomination is void, and the entrance money or forfeit is not due. 


\section{RULE 14.}

NOMINATION OF FOREIGN HORSES.

No horse foaled out of the United States shall run for any race until his owner has produced a certificate of some racing club of the country where the horse was foaled, or from the mayor or other public officer of the district, stating the age, pedigree and color of the horse, and the marks by which it is distinguished; or has produced other evidence of identity satisfactory to the Executive Committee.

\section{RULE 15.}

FRAUDULENT ENTRY A PERPETUAL DISQUALIFIOATION.

If a horse should fraudulently run, or be entered to run for any race by a false description, such horse is thenceforth disqualified for running in any race, and the owner shall be compelled to returu any sum of money won in any race, which the horse may then and thereafter have won.

When a horse has been struck out of an engagement by the person legally entitled to do so, if the horse be permitted to start by mistake for the said engagement, he shall not be entitled to receive the prize or stakes though he come in first.

If any horse has been allowed to start in consequence of fraud or false statements on the part of the owner or other person having charge of the horse, that person shall be ruled off the Course, and the horse shall be disqualified for running for any race thereafter.

\section{RULE 16.}

QUALIFIOATION DATES FROM TIME OF OLOSING.

In naming or entering for any race where there shall be any particular conditions required as a qualification to start, it shall be sufficient if the horse was qualified at the expiration of the time allowed for naming or entering, and he shall not be disqualified by anything which may happen after the expiration of that time, unless so specified in the article, or unless La $: 00$ me disqualified 
under the rules relating to defaulters. If a brood mare engaged in a produce stake drops her foal before the first of January, the nomination is void; and if she has a dead or more than one foal, or is barren, the nomination is void.

\section{RULE 17.}

NOMLATIONS NOT TO BE OHANGED AFTER CLOSING.

No person who has once subscribed to a stake shall be allowed to withdraw his name, or to substitute that of another person; and no nomination or entry shall be altered in any respect after the time of closing, without the consent of all the parties in the race.

\section{RULE 18.}

RXOEPTION TO THE PREOEDING RULE.

When a person takes a nomination for a stake in which the forfeit is to be declared by a particular time, and does not declare forfeit by the time fixed in the article, he shall thenceforth be considered to have taken the engagement on himself, and shall be held equally liable with the original subscriber.

\section{RULE 19.}

\section{USE OF FIJTITIOUS NAMES.}

Every person who wishes to engage his horses in any other name than his own, must assume some one other name, which must be registered with the Clerk of the Course; and he cannot enter or subscribe in any other until he resumes his own name. The person registering the assumed name shall be considered in all rospects as the owner of the horse entered in it, and in the event of the forfeit not being paid, his real name shall be published in the forfeit list.

No person shall register, as an assumed name, that of any person who runs his.horses in his own or in an assumed name; nor shall the real or assumed name of any person who has run horses in the Cnited States within twenty years, be registered.

Any horse running in any other name than that of his owner, shall be disqualified, unless the nane is registered as above. Any 
one owning an interest-in the racing qualities of a horse shall be considered an owner.

This rule not to prevent a person who has subscribed to a stake from giving his nomination, provided the real or reg stered name of the owner appear in the entry.

\section{RULE 20.}

\section{UNAUTHORIZED NOMINATION.}

Any person entering or naming a horse for a race without authority from the owner, shall be responsible for the stake or forfeit; entrance money shall be retained and added to the prize; and the horse shall be disqualified for running in any race until the stake or forfeit is paid, unless the owner shall have promptly disavowed the act by letter, addressed to the Clerk of the Course. Publication of the entry or nomination shall be held as notice to the owner. If it shall appear to the Executive Committee that the authority denied has been granted, the owner shall also be responsib?e for the stake or forfeit, and the horse shall be disqualified for running in any race until it is paid; and, if the Executive Committee believe that any fraud was designed, all persons implicated therein shall be ruled off the Course.

\section{RULE 21.}

NOMINATIONS NOT REQUIRED TO BE MADE ON SUNDAY.

When the day fixed for the closing of, or naming for, any stake or purse, or for declaring forfeit or produce, shall fall on Sunday, subscriptions, nominations, or declarations for such stake or purse may be received on the following day; provided that there is an interval of one day between the day of closing, naming or declaring, and the day of running.

\section{RULE 22.}

ALLOWANCE OF WEIGHT IN OERTAIN OASES.

In every race in which there is an allowance of weight to the produce of untried horses or mares, it shall extend to horses and 
mares whose produce have never won a registered prize in any country; but such allowance shall not be made unless claimed before the expiration of the time for naming, and shall not be lost by winnings after that time.

\section{RULE 23.}

NOMINATIONS IN STAKES IN EVENT OF DEATH.

All nominations in stakes are void by the death of the subscriber, except where a horse is sold with his engagements, and a written acknowledgment from both purchaser and seller has been delivered to the Clerk of the Course, previous to the death of the original subscriber.

If any of the parties to a joint nomination die, all its privileges and responsibilities attach to the survivors.

The death of a horse does not release the nominator or purchaser from liability for a stake or forfeit.

\section{RULE 24.}

ENTRIRS IN PURSES NOT VOID BY DEATH.

Entries in purses are not void by the death of the nominator, and are transferred to and become the privilege of the actual owner, unless the horse has been sold without his engagements.

Entrance money for a purse is not to be returned on the death of a horse, or his failure to start.

\section{RULE 25.}

RESPECTING STAKES AND FORFRITS.

All stakes shall be put in the hands of the Clerk of the Course before the riders are weighed. On the deposit of a stake, the right to forfeit ceases. When any person has more than one nomination in a stake, he shall not be allowed to start any horse for it unless the forfeits be paid for every horse which does not start belonging to him, or standing in his name, or in the same name as the horse which runs, as well as the stakes for those which do. 
RULE 26.

ARREARS OF OWNERS AND NAMERS TO BE PAID BEFORE STARTING.

No person shall start a horse for any race, either in his own name or that of any other person, unless both the owner and namer of such horse shall have paid all former stakes and forfeits; and this rule shall extend to forfeits due on the Course of any recognized association, if they have been published in the forfeit list of the American Jockey Club.

\section{RULE 27.}

ARREARS DUE FOR A HORSE TO BE PAID BEFORE HE CAN START.

No horse shall start for any race unless all former stakes and forfeits due for that horse be paid before starting, including those due on other Courses, if published as above.

\section{RULE 28.}

THE FORFEIT LIST.

A list of unpaid forfeits, with the name of the subscriber to the stake, and of subsequent purchasers with the engagement, and the name or description of the horse, with the name or sufficient description of the stake, and the amount of the forfeit, and the name of the person to whom it is due, shall be attached to and published with the official summary of the meeting.

A similar list of unpaid forfeits shall be published from to time, and shall be posted in the Judges' Stand, in the office of the American Jockey Club, and in the subscription room.

Forfeits due on the Course of any recognized association shall be placed in the forfeit list upon official information, or the written declaration of the person to whom such forfeit is due, verified, if need be, to the satisfaction of the Executive Committee.

The posting of a forfeit list in the office of the American Jockey Club, and at the Judges' Stand, for 24 hours, shall be sufficient publication. 


\section{RULE 29.}

PERSONS APPEARING IN FORFEIT LIST DISQUALIFIED.

No person whose name shall appear in the published forfeit list shall be entitled to enter or run a horse for any race whatever, either in his own name or in the name of any other person, until he shall have paid up all the forfeits in respect of which his name appears in the list.

\section{RULE 30.}

HORSES APPEARING IN FORFEIT LIST NOT QUALIFIED TO BE ENTERED.

No horse which appears in the published forfeit list shall be qualified to be entered or to run for any race whatever until the forfeits mentioned in the said list, as due for such horse, shall have been paid.

\section{RULE 31.}

STRIKING OUT OF ENGAGEMENTS.

No horse shall be considered as struck out of his engagement unless the declaration be made by the owner or some person authorized by him, to the Clerk of the Course or to the Secretary, who shall record the day and hour of its receipt, and give early publicity thereto.

The striking of a horse out of his engagement is irrevocable.

\section{RULE 32.}

овJEOTIONS. .

Should any horse in the published forfeit list, or any horse struck out of his engagement, be permitted to start by mistake, he shall be liable to objection at any time before the conclusion of the race meeting, unless he should also be liable under Rule 15, when objection may be made at any time within one year.

Objections to horses on the ground of non-payment of stakes or forfeits for races of the meeting in progress are not valid, unless made before the horses are ordered to the starting post. 


\section{RULE 33.}

SUSPECTED NOMINATIONS MAY BE STRUOK OUT.

In order to prevent persons who are defaulters, or who are ruled off the course, from evading these laws, and continuing to engage horses by the use of fictitious names, the Executive Committee shall have the power of calling upon a nominator, to produce satisfactory testimony that the horse named is not the property, either wholly or in part, of any person whose name appears in the published list of defaulters, or of any person ruled off the course, and, if the nominator shall fail to do so, the Executive Committee may cause the nomination or entry to be erased.

\section{RULE 34.}

LIABILITY FOR ENGAGEMENTS OF HORSES SOLD.

When a horse is sold with his engagements, or any part of them, the seller has not the power of striking the horse out of the engagements with which he is sold; but as the original subscriber remains liable to the respective winners for the amount of the forfeits in each of these engagements, he may, if compelled to pay them by the purchaser's default, place the forfeit on the forfeit list by a written declaration, in the usual manner, as due from the purchaser to himself, and until this forfeit is repaid, both the purchaser and the horse remain under the same disabilities as if the purchaser had been the original subscriber. In all cases of sale by private treaty, the written acknowledgment of both parties that the horse was sold with his engagements is necessary to entitle either buyer or seller to the benefit of this rule; but when the horse is sold by public auction, the advertised conditions of sale are sufficient evidence, and if he has been claimed as the winner of a race of which it was a condition that the winner was to be sold with his engagements, this also is sufficient.

When a horse is sold without his engagements, the seller may grant or refuse to the purchaser the privilege of starting for any of them. 


\section{RULE 35.}

FORFEITS PAID AS ABOVE MAY BE PLAOED ON FORFEIT LIST.

When a person has a horse engaged in the name of another person, and is entitled, by purchase or otherwise, to start the horse for such engagement, but is prevented by any of the preceding laws, from starting his horse without previously paying up forfeits to which he is not otherwise liable, he may, if he pays these forfeits, start his horse and have the forfeits with the names of the horses for which they are due, placed on the forfeit list, by a written declaration, in the usual manner, as due to himself.

\section{RUIE 36.}

FEATHER-WEIGHT.

Feather-weights shall be considered seventy-five pounds; the usual declaration must be made when the jockey carries above that weight.

\section{RULE 37.}

WELTER-WEIGHTS.

Welter-wreights shall be forty pounds added to weight for age.

\section{RULE 38.}

OF NAMES AND NUMBERS.

The name of every horse intended to start in any race must be notified to the Clerk of the Course, and his number be exhibited, ten minutes before the race; and if any alteration be made in the numbers after they have been exhibited, the Judges may call upon the owner, or trainer, or jockey, for an explanation. If this is not satisfactory, the owner or trainer may be fined, at the discretion of the Judges, in any sum not exceeding $\$ 250$, and the horse shall not be allowed to start in another race until the fine is paid.

\section{RULE 39.}

TO WEIGH BEFORE AND AFTER RACE.

A jockey is required to show the weight his horse is to carry to the Clerk of the Course, at the usual place of weighing, at least 
ten minutes before the race, unless excused by the Judges for some special reason, in which case the fact must be notified to the Clerk of the Course. Otherwise, the horse shall not be allowed to start in the race.

Every rider shall, immediately after the race or heat, ride his horse to the usual place of weighing, then and there alight, after obtaining the consent of the Judges, and not before, and weigh to the satisfaction of the Clerk of the Course; before doing which, he is forbidden to touch anything beyond the equipments of his horse.

Until ordered to dismount by the Judges, the rider must not suffer any person to touch or put cover on his horse. The person unsaddling the horse shall, as soon as the saddle and equipments are removed, hand them to the rider, who shall immediately carry them to the scale to be weighed. If the rider be disabled by an accident to himself or horse which should render him incapable of riding back, he may walk or be carried to the scale.

If the jockey dismounts without permission, or otherwise violates this rule, his horse is disqualified for winning the race, unless he can allege extraordinary circumstances, the sufficiency of which must be decided by the Judges.

If a jockey riding a beaten horse does not return to weigh, or give reasons satisfactory to the Judges for not so doing, he shall be fined not less than. $\$ 25$ nor more than $\$ 100$, and shall not ride until the fine is paid; and if it can be proved that the owner or trainer connived at this violation of the law, they shall be fined $\$ 100$ each, and the horse shall be disqualified for running in any race until all the fines are paid.

The jockey is to be weighed with all the equipments of his horse, except the bridle, which it is optional with him to weigh, unless required to do so by the Clerk of the Course. No whip, or substitute for a whip, shall be allowed in the scales in order to make weight, but if one has been carried by the jockey, its weight shall 
be reported to the Judges by the Clerk of the Course, in case the weight thus carried would be sufficient to disqualify the horse. An allowance of $1 \mathrm{lb}$. will be made for a curb or double bridle, but no weight is allowed for a snaffle bridle, unless it is put in the scale before the horse is led away.

Horses not bringing out the weight shown before the race, or within $1 \mathrm{lb}$. of it, shall be disqualified for winning the race; but the Judges may make allowance for overplus occasioned by rain or mud.

\section{RUIE 40.}

OVER-WEIGHT.

Each jockey shall be allowed two pounds and no more, above the weight specified for his horse to carry (all allowances to which he is entitled being deducted), unless a declaration of the extra weight the horse is about to carry has been made to the Clerk of the Course at least ten minutes before the race; and the extra weight shall be announced or appended to the horse's number when it is put up; and the weight each horse actually carried, if more than $2 \mathrm{lbs}$. above his weight, shall be stated in the published summary of the meeting; but in no case shall a horse be allowed to start carrying more than five pounds over-weight, unless the judges should be unable to decide before the race to what penalties the horse is liable, or to what allowances he is entitled, in which case he may start with any weight his owner may think proper to put up. No horse can be disqualificd for winning on account of over-weight with which he has been allowed to start.

\section{RULE 41.}

RIDERS FALLING.

If a rider fall from his horse while riding a heat or race, and another person of sufficient weight ride him in, no penalty shall be exacted for over-weight, and the horse shall not be disqualified for winning, if brought back to the spot where the rider fell. 


\section{RULE 42.}

STARTING.

The horses shall be started by a flag, and there shall be no start until, and no recall after, the Assistant Starter drops his flag, in response to the signal from his chief. The horses shall be summoned for each heat or race by the bugle-call or bell on the Judges' Stand.

\section{RULE 43.}

If any horse whose rider has been weighed, or whose number has been exhibited, does not start and run the Course, the Judges shall call upon the owner, trainer and jockey for an explanation, and if satisfactory cause be not shown, shall, at their discretion, fine, suspend or rule off the Course the parties in fault.

\section{. RULE 44.}

POWER OF STARTER.

The Starter is prohibited from making a running start; the horses must walk up, and be started from a walk. He has authority to order the jockeys to draw up in a line as far behind the starting post as he may think proper, and any jockey disobeying the orders of the Starter, or taking any unfair advantage, shall be punished by fine or suspension, at the discretion of the Starter; but the suspension of a jockey shall, in no case, take effect until after the last race of the day of his suspension.

\section{RULE 45.}

OF AIDS.

No person shall be permitted to turn or lead a horse to the post; the horses shall be started by their jockeys, and no other person shall strike a horse to get him from the post, or during the running of a race, nor shall any person stand in the track to point out a path for the rider. 


\section{RULE 46.}

OF FALSE STARTS.

When a false start is made, no horse making the false start, nor any horse remaining at the post, shall have clothes thrown upon him, or water given him, or his mouth sponged out; nor shall the rider be permitted to dismount; nor shall any delay be permitted; but the horses shall be started as soon as brought back to the post. Horses making a false start shall return to the post by the shortest way; and if the Starter perceive that a longer way is taken, he shall not delay the start for them. Any infringement of this rule shall be punished by fine or suspension, at the discretion of the Starter. When a false start is $\mathrm{m}$ ide, and a horse refuses to return to the post, the Starter may permit him to be led back behind the post, and then let loose.

\section{RULE 47.}

OF ACCIDENTS.

If an accident happen to a horse or rider, except while repeating heats, the Starter may grant a reasonable delay, not to exceed fifteen minutes, which, in extreme cases, may be extended by the Judges.

\section{RULE 48.}

OF BOLTING.

If any horse shall run from the Course into the field, he shall be disqualified for winning the race, although he may come out ahead, unless he turn and again enter the Course at the point from which he swerved.

\section{RULE 49.}

FOUL RIDING.

If, in running for any race, one horse shail cross or jostle another, so as to impede him, such horse is disqualified for winning the race, whether such cross or jostle happened by the foul or careless riding of the jockey, or by the swerving of the horse, unless it shall appear to the Judges that he w. Is forced from his track by a 
cross or jostle, or through the foul riding of other horses, in which case the penalty shall apply only to the horse or horses primarily in fault. A leading horse is entitled to any part of the Course, but if he swerves to one side when a horse is so near him that the latter is compelled to shorten his stride, it is deemed a cross.

If during the running of a race a jockey does any act of violence to another jockey or horse, or rides his horse either willfully or carelessly, so as to injure another horse, his horse is disqualified for winning the race.

If the Judges are satisfied that the riding of a race was intentionally foul, or that the jockey was instructed or induced so to ride, all persons guilty of complicity in the offence shall be ruled off the Course.

When a horse is disqualified under this rule, the penalty attaches to every horse in the race belonging wholly or in part to the same owner.

Complaints can only be received from the owner, trainer, or jockey of the horse alleged to be affected, and nust be made to the Judges either before or immediately after his jockey has passed the scales.

In steeple chases and hurdle races, the penalties provided in this rule are not applicable, unless, in the opinion of the Judges, the foul riding was deliberate and intended to jeopardize the chance of success of another horse in the race.

\section{RULE 50.}

\section{WHEN HEAT IS VOID.}

If the start takes place on the wrong side of the starting post, or if no person officially appointed occupies the Judges' Stand, the heat or race is void, and must be run again-in twenty minutes, if the distance to be run is two miles or less, and in 30 minutes if over two miles. 


\section{RULE 51.}

\section{WINNER OF A HEAT OR RAOE.}

The horse that first gets his head to the winning post shall be considered the winner of the heat or race.

\section{RULE 52.}

OF HEATS.

In a race of heats, the horse that actually wins two heats, or distances the field, wins the race. A horse running in any two consecutive heats, without winning or running a dead heat, cannot start again in the race. When a race is won by two heats, the preference of the horses is determined by the places they get in the second heat. If more than two heats are run, the horses starting for the deciding heat shall alone be placed in the race. Horses started and drawn before a race of heats is won, are held to be distanced.

\section{RULE 53.}

IN HEAT RAOES, ONLY ONE HORSE OR ONE RIDER IN SAME INTEREST CAN START.

No person shall start more than one horse of which he is the owner, either wholly or in part, either in his own name or that of any other person, for any race of heats; nor shall two riders from the same stable be permitted to ride in such race.

\section{RULE 54.}

HORSES NOT TO BE DRAWN DURING RAOE OF HEATS.

Any person who shall sell or draw his horse (if by the sale the horse be drawn) during the pendency of a race of heats, unless by permission of the Judges, shall be ruled off the Course.

\section{RULE 55.}

\section{OF TIME BETWEEN HEATS.}

The time between heats shall be-

In mile heats............................................20 minutes.

In two mile heats........................................25 minutes. 
In three mile heats .35 minutes.

In four mile heats. .40 minutes.

\section{RULE 56.}

OF DEAD HEATS.

If for any race not to be run in heats, the first two or more horses shall come in so near together that the Judges shall not be able to decide which won, those horses only shall run for such prize over again, after the last race on the same day, but at an interval of not less than thirty minutes. The other horses which started are deemed losers, and are entitled to their respective places, as if the race had been finally determined the first time.

When a dead heat for a race not of heats is run, the owners of the horses making the dead heat may agree to divide the prize or stakes, and thus terminate the race, if the conditions of the race do not prevent, but the terms of the division must be made known to the Clerk of the Course.

\section{RULE 57.}

EFEEOT OF DIVIDING AFTER A DEAD HRAT.

When horses run a dead heat for any race not to be run in heats, and the parties agree to divide the stakes, such horses shall be liable to carry extra weight as winners of that race, whether one of the horses walk over for a deciding heat or not, and if there is any money for the second horse, they divide that also.

\section{RULE 58 .}

DEAD HEAT FOR SEOOND PLAOE.

When horses run a dead heat for the second place, they divide any money that may be payable to the second horse, and if there is any money for the third, they divide that also ; and if any of these horses run for a race in which there is a penalty for having received a certain amount of money as second horse, they shall be considered as having received only the amount of their respective shares. 
When a dead heat is declared for the second place in any race, and the winner is disqualified too late for the race to be run again on the same day, the horses that ran the dead heat shall divide the race without either of them being called upon to walk over, and if any horse was placed fourth, he shall receive any money there may have been for the third.

\section{RULE 59.}

WHEN ENTITLED TO SEOOND MONEY.

When it is a condition of a stake or purse, that the owner of a second horse shall receive a certain sum of money out of the stakes or entrance money, and the race is walked over for, or no second horse is placed, the winning horse is entitled to the whole. If the money advertised to be given to the second horse is a separate donation from the race fund or other source, and the race is walked over for, or no second horse is placed, the money is not given at all.

\section{RULE 60.}

OF DISTANCING.

All horses whose heads have not reached the distance post as soon as the leading horse arrives at the winning post, are distanced, but as indispensable proof of the fact, the distance judge must have dropped his flag in response to the Judge's flag.

In heats of one mile, 40 yards shall be a distance.

In heats of two miles, 50 yards shall be a distance.

In heats of three miles, 60 yards shall be a distance.

In heats of four miles, 70 yards shall be a distance.

\section{RULE 61.}

EFFEOT OF DISQUALIFIOATION.

In running the best of heats, horses disqualified for winning are to be held as distanced; and in other races are not to be placed. Whenever a horse which has come in first is disqualified, the heat or race shall be awarded to the next best horse which is qualified. 


\section{RULE 62.}

OF SELLING RAOES. HOW THE WINNER MAY BE OLAIMED.

When it is made a condition of any race that the winner shall be sold for any given sum, the owner of the second horse being first entitled, etc., no other person than one who ran a horse in the race shall be entitled to claim. The claim must be made to the Judges or Clerk of the Course within a quarter of an hour after the race. The horse claimed shall not be delivered until the amount is paid to the Clerk of the Course, and he must be paid for by ten o'clock at night on the day of the race, otherwise the party claiming shall not be entitled to demand the horse at any future period; but, nevertheless, the owner of the horse may insist upon the claimant taking and paying for the horse claimed.

\section{RULE 63.}

OF SALES BY AUOTION.

When it is a condition of a selling race that the winner shall be put up at auction after the race, any surplus which may thereby be obtained over and above the price for which the horse was entered to be sold, shall be paid to the owner of the second horse, and this shall not invalidate the privilege of the second horse as to the prior claim of any beaten horse, under Rule 64 .

\section{RULE 64.}

CLAIM OF BEATEN HORSES.

Any horse running for a selling race is liable to be claimed by the owner of any other horse in the race for the price of which he is entered to be sold and the amount of the stake, delucting therefrom any sum he may receive by the conditions of the race-the owner of the second horse to be first entitled to claim, and the others in the order in which their horses are placed, and the winner to have the last claim. 


\section{RULE 65.}

\section{A PERSON CAN CLAIM BUT ONE HORSE.}

No person can claim more than one horse in the same race, and if two or more persons equally entitled wish to claim, they shall draw lots for the priority.

\section{RULE 66.}

FAILURE TO DELIVER OR PAY FOR HORSES.

Any person who refuses to deliver or fails to pay for a horse purchased or claimed in a selling race, shall be ruled off the Course.

\section{RULE 67.}

IN CASE OF DISQUALIFIOATION.

If a horse claimed or purchased in a selling race should subsequently be disqualified, the claimant or purchaser shall have the option of keeping it at the price of a beaten horse, or returning it immediately.

\section{RULE 68.}

- EXTRA Weights aNd allowaNoes.

When it is the condition of any race that horses should carry exira weight for winning a certain number of prizes during the year, such winnings shall date from the 1st of January preceding, shall extend to the time of starting, unless otherwise specified, and shall apply to all established races in any country.

No allowance shall be made for having been beaten a certain number of times.

If not otherwise specified, winnings, extra weights and allowances are not accumulative, but extend to the time of starting, unless a horse, entered or named for a race in which any particular conditions are required as a qualification to start, would thereby be disqualified.

A match or a private sweepstakes - that is, one to which no money has been added, and which has not been publicly advertised previous to the engagement being made-does not subject a horse to 
extra weight or entitle him to allowance. A horse walking over or receiving forfeit, except for a match or private sweepstakes, is deemed a winner.

Winners or losers of hurdle races or steeple chases are not considered winners or losers in flat racing.

\section{RUIE 69.}

\section{VALUE OF PRIZES, HOW OALCULATED.}

In estimating the value of any prize, no deduction shall be made, except of the winner's own stake, or entrance money, and of any sum or sums required by the conditions of the race to be paid out of the stakes or entrance money to the owners of any other horse or horses in the race.

The value of any prize not of money or paid in money shall not be estimated.

\section{RULE 70.}

\section{OBJECTION TO QUALIFIOATION.}

When the age or qualification of a horse is objected to, either before or after running for any race, the Executive Committee, or those whom they may appoint, shall have power to order an examination of the horse's mouth, and to call for all such evidence as they may require, and their decision shall be final. If the disqualification is made out, and they believe that the horse was entered fraudulently, all persons implicated in the fraud shall be ruled off the Course.

\section{RULE 71.}

WHEN OOMPLAINTS MUST BE MADE.

All complaints of foul riding, or of horses not running the proper course, or of any other irregularities occurring in the heat or race, must be made to the Judges by the owner, trainer, or jockey of a horse in the race, either before or immediately after his jockey has passed the scales. Objections to winning horses on other grounds cannot be entertained unless made to the Executive Committee before the conclusion of the race meeting, save and 
excepting charges of fraudulent entry, or of running horses under a false description, which may be investigated at any period within one year from the date of the offence.

\section{RULE 72.}

OBJEOTIONS TO QUALIFIOATION, WHEN TO BE MADE.

When the qualification of any horse is objected to, by ten o'clock on the morning of the day of the race, the owner must produce evidence to prove the qualification, satisfactory to the Executive Committee or Clerk of the Course before the race is run; and if he shall start his horse without doing so, the prize shall be withheld for a period to be fixed upon by the Executive Committee, at the expiration of which time, if the qualification be not proved to their satisfaction, he shall not be entitled to the prize, though his horse shall come in first, but it shall be given to the owner of the second horse. When the qualification of a horse is objected to after that time, the person making the objection must prove the disqualification.

\section{RULE 73.}

\section{EMPLOYMENT OF RIDERS AND GROOMS.}

No owner or trainer shall engage a rider or groom from another stable, who has not a certificate of good conduct, or a written consent to his re-engagement, from his last employer.

If the certificate is unjustly refused, or for any reason the consent cannot be obtained, the Executive Committee may authorize the engagement. After due notice of the complaint, either personally or by letter addressed to his usual post-office, the Executive Committee shall fine any person infringing this rule not less than $\$ 100$, and may rule him off the Course.

\section{RULE 74.}

\section{JOOKEYS.}

If a jockey rides a race without the consent of his employer, the Executive Committee may fine or suspend him, and may also fine or suspend the owner or trainer for whom he rode. 
If a jockey unattached to a stable refuses to fulfill an engagement, the Executive Committee may fine or suspend him.

\section{RULE 75.}

FOR THE PROTEOTION OF RIDERS, ETO.

Any owner or trainer, who shall owe any rider or groom more than three months' wages, payment of which has been refused, shall, upon proof of the fact satisfactory to the Executive Committee, be ruled off the Course. The Executive Committee shall not entertain any complaint, under this rule, unless it is attested by the affidarit of the creditor before a magistrate, and substantiated by evidence satisfactory to them, and shall not impose the penalty until they have given to the person owing such wages, reasonable notice of the complaint, either personally or by letter addressed to his usual post-office; and they shall remove the disability upon proof satisfactory to them of the payment of the debt.

RULE 76.

PERSONS EXPELLED FROM OTHER OOURSES.

Every person who is expelled from or ruled off the Course of any racing Association recognized by the American Jockey Club, is necessarily ruled off every Course under its control.

\section{RULE 77.}

OF DEOORUM.

If any owner, trainer, jockey or attendant of a horse use improper language to the officers of the Club, he shall be ruled off the Course.

\section{RULE 78.}

OF PERSONS ALLOWED ON OOURSE DURING RAOE.

After the horses are ordered to the starting post, and until the Judges direct the gates to be re-opened, no person except the racing officials and the owners, trainers and immediate attendants of the horses in the race, shall be allowed on the Course to be run over. 


\section{RULE 79.}

POWERS OF EXECUTIVE COMMITTEE.

When there is no specified penalty for violation of the racing rules or of the regulations of the Course, the Executive Committee have the power to fine, suspend, expel or rule off the Course.

\section{RULE 80. \\ PAYMENT AND DISPOSAL OF FINES.}

All fines must be paid within twenty-four hours. Delinquents shall be ruled off the Course.

The proceeds of all fines shall be applied, under the direction of the Executive Committee, to the relief of sick and disabled riders aud grooms.

\section{RULE 81.}

CASES UNPROVIDED FOR.

In all matters relating to the races, or running of a race, not provided for in these rules, the Executive Committee and Judges shall decide according to the best of their judgment and the usages of the turf. 


\section{CHAPTER NINETEENTH.}

\section{BETTING RULES.}

\section{RULE 1.}

In all bets, there must be a possibility to win when the bet is made. "You cannot win where you cannot lose."

\section{RULE 2.}

Bets go as the prize or stakes go. If, however, an objection be made and sustained, to the qualification of a horse, on the ground of incorrect pedigree or nomination or other defect in his engagement after the race is run, the bets shall go to the horse that comes in first, provided he is of the right age, and in other respects has not transgressed the rules of racing; but if the owner of a horse, or a person on his behalf, succeed by fraud or by false statements in starting him for a race for which he is legally disqualified, making himself liable to the penalties in Rule 15 of Racing Rules, the bets will go with the prize or stakes, whether any objection be made either before or after the race.

\section{RULE 3.}

All bets are play or pay, unless otherwise stipulated.

\section{RULE 4.}

All double bets must he considered play or pay.

\section{RULE 5.}

Confirmed bets cannot be off, except by mutual consent or by failure to make stakes at the time and place which may have been agreed upon, in which case it is optional with a bettor not in default 
to declare then and there that the bet stands. If at the time specified for making stakes, the horse or horses backed are dead or struck out of the engagement, and a start has not been stipulated, the bettor against them need not, while the backer must deposit his stake. If there is no stipulation when the bet is made for the deposit of stakes, they cannot be demanded afterward. Bets between members of the subscription room are not governed by this rule where it conflicts with any regulation or practice there established.

\section{RULE 6.}

All bets on matches and private sweepstakes depending between any two horses, are void if those horses become the property of the same person or his confederate, subsequently to the bets being made.

\section{RULE 7.}

Unless agreed by parties to the contrary, all bets between particular horses are void if neither of them is placed in the race; except bets between particular horses started for a race of heats, but not starting for a third heat, which shall be determined by their places in the second heat, and bets between such horses and a horse starting for a third heat, which are won by the latter, even though he be distanced afterward.

\section{RULE 8.}

If any bet shall be made by signal or indication after the race has been determined, such bet shall be considered fraudulent and void.

\section{RULE 9.}

The person who lays the odds has a right to choose a horse or the field; when a person has chosen a horse, the field is what starts against him.

\section{RULE 10.}

If odds are laid without mentioning the horse before the race is over, the bet must bè determined by the state of the odds at the time of making it. 


\section{RULE 11.}

When a race is postponed, all bets must stand; but if the slightest difference in the terms of the engagement is made, all bets before the alteration are void.

\section{RULE 12.}

Bets made on horses winning any number of races within the year shall be understood as meaning between the 1st of January and the 31st of December, both inclusive.

\section{RULE 13.}

If a bet is made between two horses, with a forfeit affixed-say $\$ 100$, half forfeit-and both horses start, either party may declare forfeit; and the person making such a declaration would pay $\$ 50$ if the other horse was placed in the race, but would receive nothing in the event of his horse being placed.

\section{RULE 14.}

Money given to have a bet laid shall not be returned though the race be not run.

\section{RULE 15.}

Matches and bets are void on the decease of either party before the match or bet is determined.

\section{RULE 16.}

Bets on a match for which a' dead heat is run are void; and if the match is run over again instanter, it is considered a fresh engagement.

\section{RULE 17.}

When the riders of any horses brought out to run for any race are called upon by the Starter to take their places, all bets respecting such horses shall be play or pay.

\section{RULE 18.}

When horses run a dead heat for a purse or sweepstakes, and the owners agree to divide, all bets between such horses, or be- 
tween either of them and the field, must be settled by the money betted being put together and divided between the parties in the same proportion as the prizes or stakes.

If the dead heat be the first event of a double bet between either of the horses making it and the field, the bet is void, unless one horse received above a moiety, which would constitute him a winner in a double event.

If the dead heat be the first event of a double bet between the horses making it, the bet is void, unless the division was unequal, in which case a horse receiving a larger proportion would, in a double event, be considered as better placed in the race than one receiving a smaller sum.

If a bet is made on one of the horses that ran the dead heat against a beaten horse, he who backed the horse that ran the dead heat wins the bet.

\section{RULE 19.}

If a match be run by mistake after the principals have compromised, it does not affect the betting or the result.

\section{RULE 20.}

Pools sold shall not be play or pay, unless so declared at the time. 



\section{INDEX.}

A PAGE.

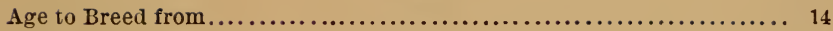

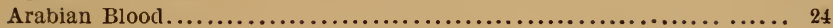

Advice to an Amateur......................................... 33

Age of Horses............................................ 38

$\mathbf{B}$

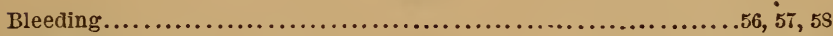

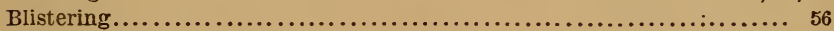

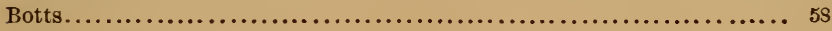

Broken Knees............................................. 59

Breeding.................................................... 5

Blindness.................................................. 11

Breeding from Pure Blood.................................... 16

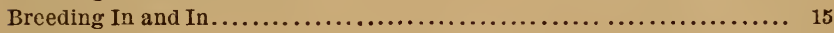

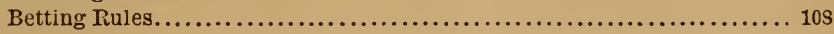

$\mathbf{C}$

Colic..................................................... 56

Cleaning Horses........................................... 48

Canadian Norman Blood .................................... 20

Curbed Horses............................................ 38

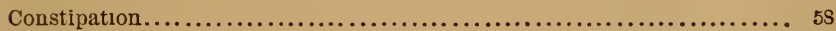

Cough................................................ 69

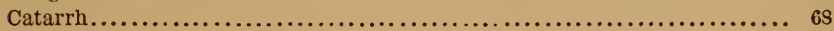

D

Diseases of Horses...................................... 54

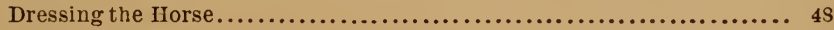

Defect in Sight............................................... 35

Difference between Mules and Hinnies....................... 30

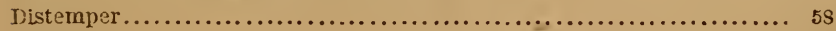

Diarrhœa................................................ 7

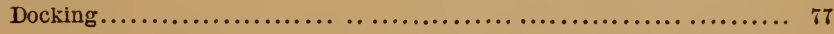


Exercise for Mare in Foal $. \ldots \ldots \ldots \ldots \ldots \ldots \ldots \ldots \ldots \ldots \ldots \ldots \ldots \ldots \ldots, 11$

Examining the Lungs........................................ 35

$\mathbf{F}$

Farcy.................................................... 64

Farcy, Remedies for................................... 64

Food for Mare in Foal. .................................. 14

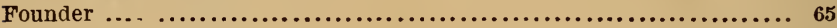

Founder, Remedies for...................................... 65

Farmers' Horses........................................... 34

G

Gripes..................................................... $\boldsymbol{7 2}^{2}$

Gripes, Remedies for....................................... 72

\section{II}

How to Buy a Horse........................................ $\$ 3$

How to Feed a Horse.......................................... 41

How to Feed Colts........................................ 42

How to Feed when Traveling............................... 45

How to Break Horses..................................... 49

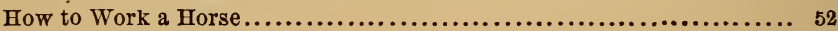

How to Shoe a Horse..................................... 80

Handling Colts........................................ 49

How to Care for Sick Animals................................ 63

How to Feed Sick Animals................................. 63

Homøpathy ............................................ 59

Hide Bound............................................... 66

Hide Bound, Remedies for $. . \ldots \ldots \ldots \ldots \ldots \ldots \ldots \ldots \ldots \ldots \ldots \ldots \ldots \ldots . \ldots \ldots$

I

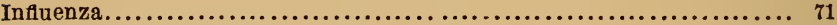

Influenza, Remedies for.................................... 72

Inflammation of the Bowels................................... 74

Inflammation of the Bowels, Remedies for.................... 74

Inflammation of the Kidneys................................ 75

Inflammation of the Brain $. \ldots \ldots \ldots \ldots \ldots \ldots \ldots \ldots \ldots \ldots \ldots \ldots \ldots \ldots \ldots \ldots \ldots \ldots, 67$

Inflammation of the Brain, Remedies for...................... 67

Inflammation of the Lungs.................................... 70

Inflammation of the Lungs, Remedies for...................... 70

Indigestion............................................... 73

Indigestion, Remedies for................................... 73

\section{$\mathbf{J}$}

Jockeying Horses' Teeth................................... 34

\section{$\mathbf{L}$}

Legs and Feet............................................ 37

Light for Horses........................................... 46 
Medicines in Balls

Mange, Remedies for

Megrims

Megrims, Remedies for

Mules.

Mules, How to Improve.

N

Nitre.

$\mathbf{N}$

Nicking.

(1)

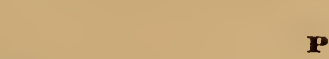

Pure Norman........................................... 22

Purgatives.................................................... 57

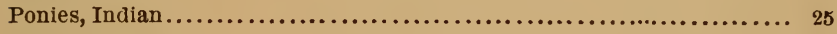

Ponies, Shetland......................................... 27

Ponies, Texan.............................................. ${ }_{26}$

Pulse................................................... 55

$\mathbf{s}$

Sore Throat............................................... $7_{0}$

Sore Throat, Remedies for.................................... 70

Strains................................................... 60

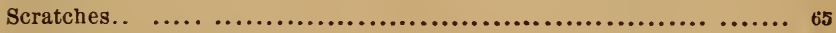

Surgeons, Veterinary........................................

Stable, The............................................ 46

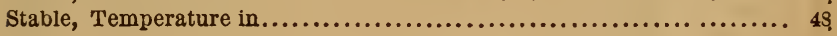

T

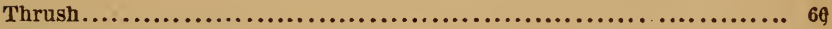

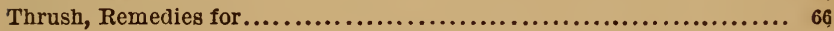

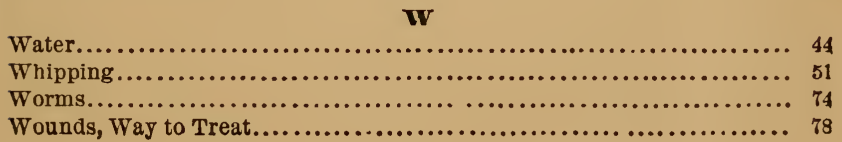




\section{INDEX TO RACING RULES.}

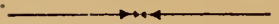

PAGE.

Accidents............................................... 97

Age of Race Horses....................................... . 82

Aids..................................................... 96

Allowance of Weight in Certain Cases.......................... 88

Arrears Due for a Horse.................................... 90

A Person can Claim but One Horse.............................. 103

A Purse................................................... 82

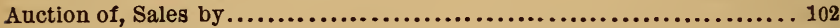

Bolting .................................................... 97

Cases Unprovided for......................................... 107

Claim of Beaten Horses..................................... 102

Closing, Qualification Dates from Time of...................... 86

Closing, Nominations Not to be Changed After................... 87

Committees, Powers of....................................... 107

Course, Persons Expelled from............................... 106

Course, Persons Allowed on.................................. 106

Day, Omissions of............................................. 84

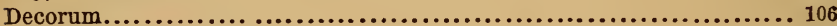

Distances, Omissions of....................................... 84

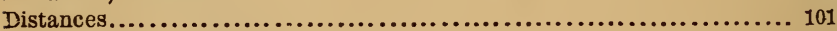

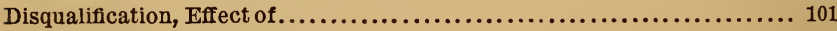

Disqualification, in Case of .................................... 103

Disqualification Fraudulent Entry, etc.......................... $8 \tilde{0}$

Disqualificatıon, Insufficient Description........................ 85

Dress and Colors............................................. 84

Employment of Riders and Grooms............................ 105

Engagements, Liability for................................ 92

Engagements, Striking out................................ 91

Entries.................................................... 85

Entries in Purses not Void by Death.......................... 89

Failure to Deliver......................................... 103

Fines, Payment of ........................................... 107

Forfeit List................................................. 90

Forfeit List, Horses Appearing............................ 91 
PAGE.

Forfeit List, Persons Appearing.

Forfeit Paid................................................... 93

Foul Riding............................................. 97

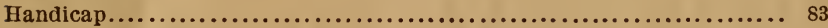

Heat, Dead................................................ 100

Heat, Dividing after Dead..................................... 1900

Heat, Dead for Second Place................................... 100

Heat, Horses not to be witharawn............................... 99

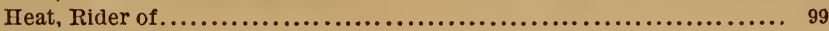

Heat, when void.............................................. 98

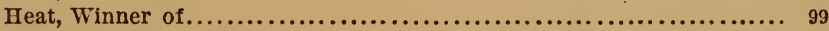

Heats, Time between....................................... 99

Jockeys.................................................... 105

Nomination of Foreign Horses............................... 86

Nomination not required to be made Sunday ...................... 88

Nomination in Stakes in event of Death......................... 89

Nomination Suspccted........................................ 92

Names, use of Fictitious................................... 87

Names and Numbers....................................... 93

Objection................................................ 91

Objections to Qualiflcations.....................................104-105

Prizes, Value of............................................. 104

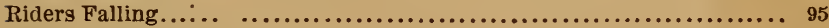

Riders, Protection of........................................ 106

Races, Selling.......................................... 102

Stake Post................................................... 83

Stakes, respecting......................................... 89

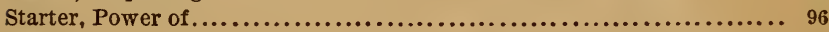

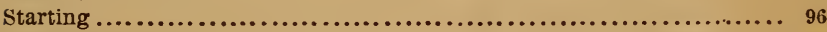

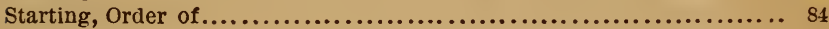

Starts, False............................................ 97

Sweepstakes.................................................. 83

Weight before and after Race................................. 93

Weight, Extra.............................................. 103

Weight, Feather......................................... 93

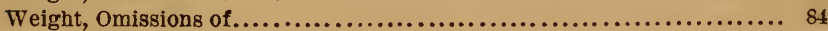

Weight, Over............................................. 95

Weight, Welter.......................................... 93 


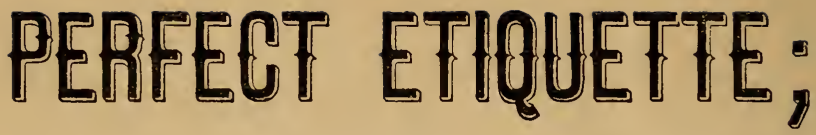

OR,

\section{HOW TO BEHAVE}

IN SOCIETY.

a Complete Manal for Ladies and Gentlemen,

\section{EMBRAOING}

Hints on Introduction, Salutation, Conversation, Friendly Visits, Social Parties, On the Street,

In Public Places, In Traveling, Driving and Riding, Letter Writing, At the Table, Making and Receiving. Presents, Courtship, Wedding Etiquette, Christening, Funerals, Etc., with Suggestions How to Dress Tastefully.

\section{포포 오포표,}

With Simple Recipes for Improving the Complexion, Etc.

Price, Illuminated Paper Cover, 30 Cents. 46 i" Board 66 50 “ SENT FREE BY MAIL ON RECEIPT OF PRICE.

ADDRESS,

\section{ALBERT COGSWELL, Publisher,} 139 EIGHTH ST., NEW YORK. 


\section{GENTLEMAN'S}

PERFEQT LETTER WRITER:

\section{Hints and Helps to Letter Writing.}

$\triangle$ COMPLETE AND INSTRUCTIVE GUIDE FOR THE

\section{CORRESP ONDENT,}

Containing a very Superior and Original Collection of Miscellaneous Businesa Letters ; Business Lotters of Introduction; Letters of Credit; Letters of Application for Employment; Letters of Application for Increase of Salary; Copies of Testimonials or Letters of

Recommendation; Familiar and Social Correspond-

ence; Social Letters of Introduction, Cen-

gratulation and Condolence; Notes of

Ceremong and Compliment.

(4)

Rules for Conducting Public Debates and Meetings; Postal

Rates and Regulations; Business Law and Business

Maxims; Interest Tables; Titles and Forms of Address, etc., etc.

PRICE, 30 CENTS, POST-PAID.

ADDEESS,

ALBERT COGSWELI, Publisher, 46 BEEKMAN STREET, N. Y. 





$$
0
$$



